\title{
FIRM AND ESTABLISHMENT VOLATILITY: THE Role OF SUNK COSTS, PROFIT UNCERTAINTY AND TECHNOLOGICAL CHANGE
}

\author{
VIVEK GHOSAL \\ CESIFO WORKING PAPER NO. 980 \\ CATEGORY 9: INDUSTRIAL ORGANISATION \\ JULY 2003 \\ An electronic version of the paper may be downloaded \\ - from the SSRN website: www.SSRN.com \\ - from the CESifo website: www.CESifo.de
}




\title{
FIRM AND ESTABLISHMENT VOLATILITY: THE ROLE OF SUNK COSTS, PROFIT UNCERTAINTY AND TECHNOLOGICAL CHANGE
}

\begin{abstract}
The degree of endemic volatility in the number of firms and establishments varies considerably across industries. Examining the within-industry range of variation (max.-min.) of the number of firms over our sample period, the low and high values across U.S. manufacturing industries are 4 and 3,500 firms respectively, with a mean value of about 324 firms. This reveals that (1) the typical industry experiences significant fluctuations in the number of firms and (2) there are large cross-industry differences in this dimension. Theory suggests several potential factors that might explain this dispersion of firm volatility across industries: for example, sunk capital costs, uncertainty about profits and technological change. An advantage of the manufacturing industry dataset we have assembled for this study is that it combines the annual time-series data from the Annual Survey of Manufactures with data from the five-yearly Census of Manufactures. The former allows us to measure uncertainty about profits and technological change, while the latter enables us to obtain information on the industryspecific size distribution of establishments, the number of establishments per firm and construct proxies for sunk capital costs. Our empirical findings show that: (1) industries with higher sunk capital costs and profit uncertainty have significantly lower variability of the number of firms; and (2) these relationships are non-linear as suggested by theory with initial increases in sunk costs or uncertainty having relatively greater effect on firm volatility. The effects of technological change appear to be mixed. We explore the implications of our findings for antitrust analysis.
\end{abstract}

JEL Code: L11, L40.

Keywords: firm and establishment volatility, sunk capital costs, profit uncertainty, technological change, antitrust.

\author{
Vivek Ghosal \\ School of Economics \\ Georgia Institute of Technology \\ Atlanta, GA 30332 \\ U.S.A. \\ Vivek.Ghosal@econ.gatech.edu
}

For helpful comments and discussions on earlier versions, I thank audiences at: International Industrial Organization Conference (Boston); "The Economics of Entrepreneurship and the Demography of Firms and Industries" organized by Zentrum für Europäische Wirtschaftsforschung (ZEW, Mannheim); and "Post-Entry Performance of Firms: Role of Technology, Growth and Survival" organized by the University of Bologna. I completed this paper while I was a research visitor at the Center for Economic Studies, University of Munich; I thank CES for their research support and hospitality. 


\section{Introduction}

Industries show wide variation in the volatility of the number of firms and establishments. Using data on 266 U.S. manufacturing industries over the Census years 1963-1992, Table 1 presents summary statistics on the differences across industries in the standard deviation and range of establishments and firms. For example, at the mean value, an industry shows a range (max.-min.) of 324 firms over the sample period, and the percentile distribution reveals substantial heterogeneity across industries with the low and high values being 4 and 3,500 firms respectively. While cross-industry differences in firm volatility has been extensively documented (Caves, 1998; Dunne, Roberts and Samuelson, 1988; and Sutton 1997.a), there appears to be less empirical work examining the determinants of this heterogeneity. The central question this paper seeks to shed light on is: What underlying factors contribute to the crossindustry differences in the volatility of the number of firms and establishments?

While theory points to some usual suspects, like sunk capital costs, uncertainty about profits and technological progress, there appears to be little work in quantification of these measures and relating them to firm volatility. Sunk capital costs act as a barrier to entry. This is likely to lower entry and, consequently, exits, resulting in lower variability of the number of firms. In Section 2.1 we review the theory related to sunk costs. It is well established that greater uncertainty about profits raises (lowers) the entry (exit) trigger price (Dixit, 1989). This implies that industries with greater uncertainty may be subject to less entry and, consequently, exits, resulting in reduced firm variability. In Section 2.2 we present the underlying theoretical issues related to uncertainty. Numerous papers have examined the link between technological progress and the patterns of entry and exit. As we discuss in section 2.3, the impact of technological change on firm volatility is ambiguous in general and depends, in part, on whether innovations emanate from inside or outside the industry. Finally, we also address issues related to credit markets (Section 2.3), potential differences between variability in the number of small versus large firms (Section 2.5), and consider additional control variables like advertising-intensity and industry growth (Section 3.5) that may influence variability of the number of firms.

The details about data and measurement of industry-specific variables related to sunk costs, 
uncertainty, technology, and others are presented in Section 3; some of the details related to measurement of sunk costs and technical change are relegated to the appendix. Section 4 presents our empirical models and estimation results. Our empirical findings reveal that industries with higher sunk costs and uncertainty have significantly lower variability of the number of firms and establishments. The theory (Section 2) suggests that initial increases in sunk costs or uncertainty are likely to induce relatively greater entry/exit hysteresis and reduce firm volatility than subsequent increases. We find evidence in favor of such non-linear relationships. The technology effects are mixed. Using R\&D intensity to proxy technical change, we find that industries with greater $R \& D$ have low er variability in the number of firms. But using a factor-utilization-adjusted total factor productivity (TFP) measure, we do not get clear answers. Our findings on sunk costs and uncertainty, in particular, can be useful for research in several areas. In Section 5 we comment on the implications of our findings for the analysis of competitive effects and entry in antitrust/competition policy. ${ }^{1}$

\section{Theory and Predictions}

\subsection{Sunk Entry Capital Costs}

For the $\mathrm{i}^{\text {th }}$ industry, let $\mathbf{K}$ be the entry capital requirement, $\mathbf{r}$ the unit price of new capital, and $\phi$ the resale/scrap price of this capital with $r>\phi$. A firm contemplating entry into this industry must take into consideration the non-recoverable component of entry investment $\Phi=(\mathrm{r}-\phi) \mathrm{K}$, the sunk cost. ${ }^{2}$ Given that characteristics of technology and capital vary considerably industries, a priori one expects wide crossindustry variation in $\Phi$. Sunk entry capital costs act as a barrier to entry and mobility. This notion has been used to understand firms' entry and exit decisions (e.g., Baumol, Panzar and Willig, 1982; Caves and Porter, 1977; Dixit, 1989; Dixit and Pindyck, 1994) and investment behavior (e.g., Dixit, 1980; Dixit

\footnotetext{
${ }^{1}$ In this paper we examine the determinants of longer-run, or endemic, volatility of firms and establishments. Ghosal (2002) examines the short-run time-series fluctuations in uncertainty and industry structure. Given our objective of examining cross-industry differences in endemic volatility, we do not explicitly focus on models of learning and the intertemporal evolution of firms and industries (e.g., Jovanovic, 1982; Pakes and Ericsson, 1998).

${ }^{2}$ To simplify, we ignore depreciation. Sunk costs will be relevant for the non-depreciated portion of capital.
} 
and Pindyck, 1994; Spence, 1977). Two key points emerge from the literature:(1) in industries with high $\Phi$, entry will be lower and, consequently, exits will also be lower implying that the variance of firms is likely to be lower; and (2) numerical simulations in Dixit (1989, Fig.2) show that, starting with zero sunk costs, even small amounts of sunk costs induce significant entry/exit hysteresis and subsequent increases in sunk costs have a proportionately lesser effect, implying non-linearity in the relationship. ${ }^{3}$ If $\sigma($ Firms) measures volatility of the number of firms in an industry, then $\sigma($ Firms $)=g(\Phi)$, with $g_{\Phi}<0$ and $g_{\Phi, \Phi}>0$.

Empirical prediction: Industries with high sunk entry capital costs $\Phi$ are expected to show lower $\sigma($ Firms $)$. The relationship is likely to be non-linear with initial increases in $\Phi$ showing greater decreases in $\sigma$ (Firms). We estimate both linear and quadratic specifications to shed light on the relationship.

\subsection{Profit Uncertainty}

Dixit (1989) models a price-taking risk-neutral firm, with access to a given technology, that maximizes expected net present value. Let $\pi$ be a measure of profitability. ${ }^{4}$ Uncertainty is measured by the conditional standard deviation of the process generating $\pi, \sigma(\pi)$. Define a pair of entry and exit trigger prices $\mathbf{P}^{\mathrm{H}}$ and $\mathbf{P}^{\mathrm{L}}$. In the range $\left(0, \mathrm{P}^{\mathrm{H}}\right)$ the potential entrant holds on to its option to enter, and over $\left(\mathrm{P}^{\mathrm{L}}, \infty\right)$ an incumbent remains in the industry. Greater $\sigma(\pi)$ implies an option value of waiting and this raises (lowers) $\mathrm{P}^{\mathrm{H}}\left(\mathrm{P}^{\mathrm{L}}\right)$. Rise in $\mathrm{P}^{\mathrm{H}}$ lowers entry. $\mathrm{P}^{\mathrm{L}}$ falls as the firm knows it has to re-incur sunk costs upon reentry and this delays exit. Thus greater $\sigma(\pi)$ lowers both entry and exit. Numerical simulations in Dixit (1989) and Dixit and Pindyck (1994, Ch.7,8) show that: (1) the entry and exit thresholds widen significantly under greater uncertainty; and (2) starting from zero uncertainty, even small amounts of

\footnotetext{
${ }^{3}$ The simulation results show (Dixit, 1989; Dixit and Pindyck, 1994, Ch.7,8) that the rise (fall) in the entry (exit) trigger price is substantial for initial, small, increases in sunk costs. While the entry (exit) triggers continue to rise (fall) as sunk costs rise, the rate is diminishing signifying non-linearity

${ }^{4}$ The relevant stochastic element can be couched in terms of any relevant variable such as profits, cash-flows, price, among others. Caballero and Pindyck (1996) and Dixit and Pindyck (1994) discuss uncertainty about cashflows, profits, among other variables. In the simplest settings, the models consider uncertainty about prices holding constant input costs and technology; but this term is easily given a profitability interpretation.
} 
uncertainty significantly widen the entry/exit thresholds and the subsequent increases have proportionately lesser effects, implying a non-linear relationship. In short, $\sigma($ Firms $)=f[\sigma(\pi)]$, with $\mathrm{f}_{\sigma(\pi)}<0$ and $f_{\sigma(\pi), \sigma(\pi)}>0$. The figure below provides an illustration (based on the numerical results in the above papers) of $\sigma(\pi)$ and price thresholds, $\mathrm{P}^{\mathrm{H}}$ and $\mathrm{P}^{\mathrm{L}}$.

Figure: Uncertainty and the entry and exit trigger prices.

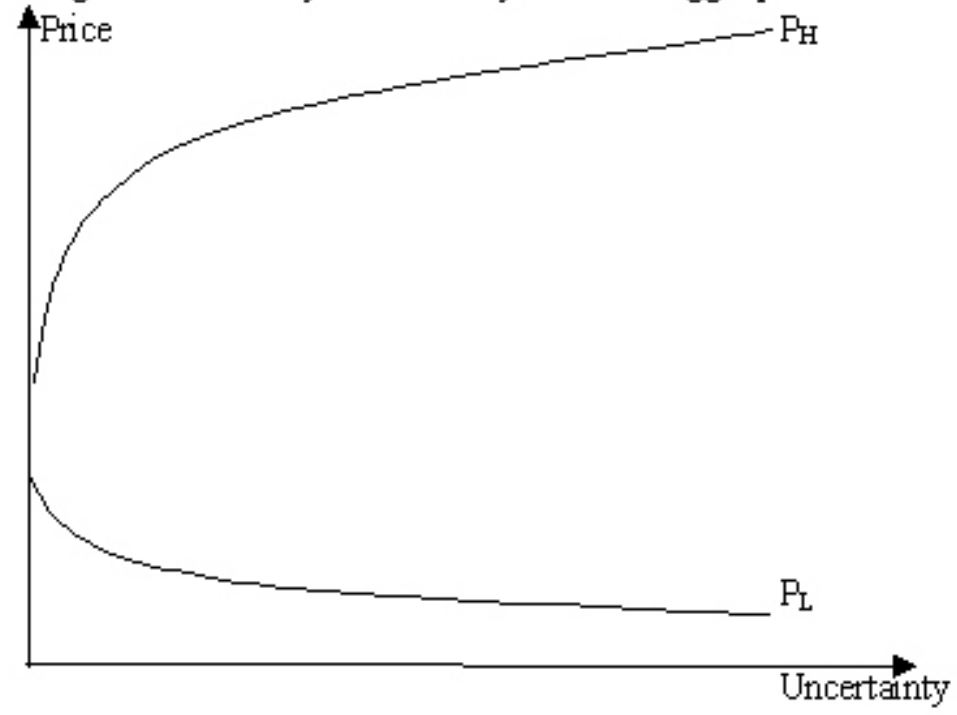

Turning to imperfect competition, Dixit and Pindyck (1994, p.309-315) show that the option value of waiting, which slows entry, remains when $\sigma(\pi)$ is greater. But an oligopolistic setting requires consideration of pre-emption by rival(s) and this may necessitate a faster response. Therefore, the net effect is ambiguous. ${ }^{5}$ The literature which examines the incentives for incumbents or first-movers in

\footnotetext{
${ }^{5}$ To briefly highlight the issues, start with two potential entrants $\mathrm{F}(1)$ and $\mathrm{F}(2)$. Let $\mathrm{F}(1)$ be the leader and $\mathrm{F}(2)$ follower. Let $\mathrm{P}(1)$ be the price at which $\mathrm{F}(1)$ enters, and $\mathrm{P}(2)$ when $\mathrm{F}(2)$ enters, $\mathrm{P}(2)>\mathrm{P}(1)$; if $\mathrm{P}>\mathrm{P}(2)$ then $\mathrm{F}(2)$ enters immediately, otherwise it waits for prices to rise above $\mathrm{P}(2)$. $\mathrm{P}(1)$ exceeds the Marshallian entry trigger due to uncertainty. Let $\mathrm{F}(1)$ earn profits $\Pi(1)$ during the interval of its sole occupancy in the industry; when $\mathrm{P}(1)<\mathrm{P}<\mathrm{P}(2) . \mathrm{F}(1)$ rationally expects profits to fall when $\mathrm{F}(2)$ enters. Entry by $\mathrm{F}(2)$ will truncate the upper end of
} 
oligopolistic markets to engage in strategic pre-commitments to erect entry barriers shows that it may be optimal for the incumbent/first-mover to pre-commit (e.g., Appelbaum and Lim, 1985; Spencer and Brander, 1992). But uncertainty lowers the optimal pre-commitment due to greater uncertainty about the success of the entry-deterring strategy. Overall, oligopolistic settings highlight the ambiguity of outcomes, which are critically dependent on model assumptions.

Empirical prediction: Industries with greater $\sigma(\pi)$ should attract lower entry and, consequently, have lower exits; $\sigma($ Firms $)$ is expected to be lower in industries with greater $\sigma(\pi)$. The relationship is likely to be non-linear with initial increases in $\sigma(\pi)$ showing greater decreases in $\sigma($ Firms $)$. The uncertainty effect is ambiguous in imperfectly competitive industries.

\subsection{Credit Markets}

Apart from the effects described in 2.1 and 2.2, there are additional reasons why $\Phi$ and $\sigma(\pi)$ may be important in influencing $\sigma($ Firms $)$. Firms often rely on external credit to enter industries and for their subsequent investment outlays and other expenditures. An important literature has highlighted the role played by profit uncertainty and sunk costs on firms' access to external credit. For conciseness, we only reference the papers directly relevant for our analysis. First, consider profit uncertainty $\sigma(\pi)$. Greenwald and Stiglitz (1990) consider a firm where decision makers maximize expected end-of-period equity minus an expected cost of bankruptcy; the latter plays a key role in decision making. The key results relevant for our analysis are that greater $\sigma(\pi)$ : (1) increases the absolute and incremental risk of bankruptcy at any level of investment since they cannot absorb the increased risk by issuing more equity,

\footnotetext{
${ }^{5}(\ldots$ continued $)$

the distribution of profit flows. Thus, $\mathrm{F}(1)$ must receive a premium before it enters. Of course, in this setting there is no mechanism determining the leader/follower: this could be determined endogenously or exogenously; who enters and when depends on the underlying conditions. Now consider simultaneous decision making and $\mathrm{P}=\mathrm{P}(1)+\epsilon$ ( $\epsilon$ is small positive). Price is above the entry threshold and since neither firm wants to wait, for the fear of being preempted by its rival, and could assume leadership role, we could get simultaneous entry. In this case entry could be faster than in the leader-follower setting described above.
} 
and (2) exacerbates borrowing constraints. Some firms are more likely to face borrowing constraints due to information asymmetries between borrowers and lenders. Therefore, the impact of greater $\sigma(\pi)$ will differ across firms, depending on the extent of financing constraints. ${ }^{6}$ Second, consider sunk costs $\Phi$. The basic result is that lenders are likely to be more reluctant to provide financing if capital embeds large sunk costs (Williamson, 1988; Shleifer and Vishny, 1992). ${ }^{7}$ If asset specificity is high then capital is likely to have low resale value; collateral has less value. Thus, greater $\Phi$ is likely to exacerbate asymmetric information problems and tighten borrowing constraints.

\section{Empirical predictions:}

Access to external credit is likely to be more difficult in industries characterized by high $\Phi$. This will lower entry. Consequently, exits will also be lower. Thus, via the credit market effects, $\sigma($ Firms $)$ is likely to be lower in industries with high $\Phi$. Similar prediction emerges for industries with high $\sigma(\pi)$.

\subsection{Technological Change}

Winter (1984) hypothesizes that when the accumulated stock of technology has emanated from within the industry via learning-by-doing and other channels ("routinized" regime), outsiders (new entrants) will have a difficult time making inroads. One way to describe the effects is as follows. It is well known that entering firms are much smaller than incumbents and these new firms are typically less efficient. In an industry primarily characterized by routinized regime, the incumbents' efficiency advantage will be greater; this asymmetry will make it difficult for entrants to compete. In equilibrium, such industries will

\footnotetext{
${ }^{6}$ The literature suggests financial market frictions are likely to affect smaller firms. See Cabral and Mata (2003), Cooley and Quadrini (2001), Fazzari, Hubbard and Petersen (1988) and the references there.

${ }^{7}$ Williamson (1988, p.571) writes: "Of the several dimensions with respect to which transactions differ, the most important is the condition of asset specificity. This has a relation to the notion of sunk cost..." (p.580) "In the event of default, the debt-holders will exercise pre-emptive claims against the assets in question.... The various debt holders will then realize differential recovery in the degree to which the assets in question are redeployable... the value of a pre-emptive claim declines as the degree of asset specificity deepens...". In Shleifer and Vishny (1992), asset specificity is a determinant of leverage and explains cross-industry and intertemporal patterns of financing; e.g., the ease of debt financing is inversely related to the degree of asset specificity.
} 
be characterized by lower entry and, consequently, lower exit. In contrast, when there is new firm innovation (Winter's “entrepreneurial” or non-routinized regime), new entrants are more competitive and entry is facilitated. Thus routinized regime is likely to have an entry-retarding effect whereas an entrepreneurial regime will be entry-facilitating. In other words, the "inside" versus "outside" industry streams of innovation are key to determining whether entry is facilitated or hindered. ${ }^{8}$ Sutton (1997.a; 1998) provides a review of the literature and additional insights. A general theme emerging from Audretsch's (1995) empirical results is that higher industry-wide innovation results in reduction of new startup firms and decreases the survival chances of new firms. His results also indicate that, in general, it is the smaller firms that are more likely to exit. In contrast, new (small) firm survival rate is much higher where new firm innovation rate is higher. These findings lend support to Winter's hypotheses.

Empirical predictions: The effect of technological change on $\sigma$ (Firms) will depend on whether the innovations are emanating from outside the industry or inside. Given that both types are likely to be prevalent, the net effect appears to be ambiguous. As noted earlier, the theory for sunk costs and uncertainty points to a non-linear relationship. For technology this is less clear. One can potentially make a similar argument that even small amounts of innovative activity emanating from, say, inside the industry (routinized regime) can have significant entry-retarding effects. Keeping this in mind, we estimate both linear and non-linear functional forms to capture the technology effects.

\subsection{Small versus Large Firms}

It is well known that firm size distribution is typically skewed; a few large firms co-exist with numerous small firms. The data shows that the "typical" entering (exiting) firm is very small compared to

\footnotetext{
${ }^{8}$ In our study we do not examine the predictions of the life-cycle models (e.g., Gort and Klepper, 1982; Jovanovic and MacDonald, 1994) because these models deal with the intertemporal life-cycle of industries from birth to maturity. Our study is concerned with which industries have endemically greater or lower volatility in the number of firms and we use a relatively mature sample of industries. However, even in the life-cycle models, innovations that emanate from outside the industry facilitate entry and lead to significant positive net entry, while innovations that emanate from within the industry lead to rise in entry barriers (Gort and Klepper, p.634).
} 
incumbents. ${ }^{9}$ This implies that when examining volatility of firms, one expects most of the action to be in the small firm category. Keeping this in mind, in our empirical analysis we present estimates of the effect of sunk costs, profit uncertainty and technological change on small versus large firm volatility. We return to this in Section 4.

\section{Measurement}

The data are from the U.S. SIC 4-digit manufacturing; the appendix provides details about sources, time periods, sample size and measurement of sunk costs and technological change.

\subsection{Industry Structure}

We collected data on the following: (i) the number of firms in an industry -FIRMS; (ii) number of establishments in an industry -ESTB; and (iii) ESTB by size classes. These data are from the 5-yearly Census of Manufactures and are not available at an annual frequency. An establishment is defined as an economic entity operating at a location. A firm can have more than one establishment. The establishment size classes are defined by the number of employees per establishment. The Census size classes are: number of employees $1-4 ; 5-9 ; 10-19 ; 20-49 ; 50-99 ; 100-249 ; 250-499 ; 500-999 ; 1,000-2,499 ; 2,500$ or greater. Given our discussion in section 2.5, use the ESTB data to define relatively small versus large establishments. The U.S. Small Business Administration(e.g., The State of Small Business: A Report of the President, 1990) classifies a "small business" as one that employs less than 500 workers. We use the 500 worker cutoff as our benchmark. Number of employees $\leq 500$ constitutes our basic small business group, and $>500$ employees as the relatively large business group. However, 500 employees may

\footnotetext{
${ }^{9}$ See Audretsch (1995), Dunne et al. (1988), Geroski and Schwalbach (1991) and Sutton (1997.a). In Audretsch (p.73-80), the mean size of the entering firm is 7 employees and varies from 4 to 15 across 2-digit industries. Audretsch (p.157-160) shows that 19\% of the exiting firms have been in the industry for less than 2 years with a mean size of 14 employees; considering exiting firms of all ages, the mean size is 23. Dunne et al. note (p.503): "On average, $38.6 \%$ of the firms in operation in each industry in each Census year were not producing in that industry in the previous Census... the entrants in each year are responsible for approximately $15.8 \%$ of each manufacturing industry's output." While the number of entrants is large, their size is very small relative to the incumbents. Data indicate a similar pattern for exiters.
} 
constitute a relatively large and wealthy business. Keeping this in mind, we create additional small business groups. Overall, our groups are: (i) All industries; (ii) relatively large businesses with $>500$ employees; (iii) relatively small businesses with $\leq 500$ employees; and (iv) even smaller businesses as

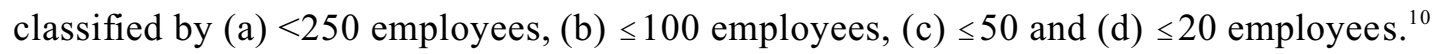

We look at two measures of volatility. In Table 1 we present the cross-industry summary statistics on the standard deviation (s.d.) and range (max.-min.) of FIRMS and ESTB, as well as by establishment size group. The data indicate substantial variation across industries in the s.d. and range. Next we look at Table 2 which presents the cross-industry distribution of the level of FIRMS, ESTB, the ratio [ESTB/FIRMS], and a broad picture of the establishment size distribution. Looking at the [ESTB/FIRMS] ratio, the $50^{\text {th }}$ percentile value is 1.12 and this rises to 1.57 at the $90^{\text {th }}$ percentile level. This indicates a rough correspondence between the number of firms and establishments in an industry. The Census does not provide data on firm size. But we have data on establishment size. Given the observation from Table 2 that there is rough correspondence between firm and establishment, we can assume that the observed size distribution of establishments and roughly mirrors the size distribution of firms. The data in Table 3 show a skewed size distribution of establishments. For example, at the median value: (1) $70 \%$ of the total number of establishments in an industry belong to the $\leq 50$ employees group; and (2) only $2 \%$ of the establishments belong to the 'larger' size group ( $>500)$.

\subsection{Sunk Costs}

In section 2 we noted that, abstracting from depreciation considerations, sunk costs corresponded to the non-recoverable component of entry capital investment $\Phi=(\mathrm{r}-\phi) \mathrm{K}$, where $\mathrm{K}$ is the entry capital requirement, $r$ the unit price of new capital and $\phi$ the resale price (or scrap value) of this capital.

\footnotetext{
${ }^{10}$ Our data are on the total number of firms and establishments in an industry, implying that we cannot examine entry and exit separately but can only study "net entry". This data-induced limitation implies that we will be unable to observe whether sunk costs, profit uncertainty and technological progress have differential quantitative effects on entry and exit. Such an analysis can be conducted where detailed data on all the variables are available. We do note that our data show considerable within-industry variation in net entry and large cross-industry differences in this dimension. This is encouraging for our empirical examination.
} 
Unfortunately, obtaining data on $\phi$ is extremely difficult implying that we can't measure $\Phi$ directly for our 266 industries. Instead, we pursue an alternate approach.

The theoretical models examined in section 2 treat sunk costs as proportional to entry capital requirements. We adopt the methodology outlined in Kessides (1990) and Sutton (1991) to obtain proxies for sunk costs. The extent of sunk capital outlays incurred by a potential entrant will be determined by the durability, specificity and mobility of capital. While these characteristics are unobservable, one can construct proxies. Following Kessides, let RENT denote the fraction of total capital that a firm (entrant) can rent: $\mathrm{RENT}=($ rental payments on plant and equipment/capital stock). Let USED denote the fraction of total capital expenditures that were on used capital goods: USED $=($ expenditures on used plant and equipment/total expenditures on new and used plant and equipment). Finally, let DEPR denote the share of depreciation payments: $\mathrm{DEPR}=($ depreciation payments/capital stock $)$. We create the following three measures:

(1) $\Phi(\mathbf{R E})=(1 / \mathrm{RENT})$;

(2) $\Phi(\mathbf{U S})=(1 / \mathrm{USED})$; and

(3) $\Phi(\mathbf{D E})=(1 / \mathrm{DEPR})$.

High $\Phi(\mathrm{RE})$ indicates low-intensity rental market, implying higher sunk costs. High $\Phi(\mathrm{US})$ signals lowintensity used capital market, implying higher sunk costs. High $\Phi(\mathrm{DE})$ indicates that capital decays slowly, implying higher sunk costs which arise from the undepreciated portion of capital.

The final measure $\Phi(\mathbf{E K})$ is from Sutton (1991); details are provided in the data appendix. This is a measure of median entry capital requirement based on the observed distribution of plant sizes. As in Sutton, sunk costs are assumed to be proportional to $\Phi(\mathrm{EK})$. We collected data to construct $\Phi(\mathrm{RE})$, $\Phi(\mathrm{US}), \Phi(\mathrm{DE})$ and $\Phi(\mathrm{EK})$ for the Census years 1972, 1982 and 1992. Using data at widely spaced points in time gives us a picture of the long-run characteristics. In our estimation, we report results with these measures entered separately. However, in our baseline specification, we use a "weighted" index of sunk costs capturing elements of all the attributes described above:

$\Phi(\mathbf{W})=\left[\delta_{1} \Phi(\mathrm{RE})+\delta_{2} \Phi(\mathrm{US})+\delta_{3} \Phi(\mathrm{DE})+\delta_{4} \Phi(\mathrm{EK})\right]$ 
where $\delta_{i}$ 's are the weights. Due to lack of information which can be used to assign optimal weights $\delta$, we assume that $\delta_{i}=0.25 \forall$ i. Table 3 presents summary statistics for $\Phi(R E), \Phi(U S), \Phi(D E), \Phi(K)$ and $\Phi(\mathrm{W})$. Figure 2 plots the raw data on $\sigma($ Firms $)$ and $\Phi(\mathrm{W})$. Table 4 presents the cross-industry sample rank correlations between $\sigma($ Firms $)$ and $\sigma($ Estb $)$ and the various sunk costs measures. These reveal a negative relationship between sunk costs and firm and establishment volatility.

\subsection{Uncertainty}

While theory suggests several variables that can be used to measure uncertainty, we use a bottom-line measure - profitability - which is a key concern for firms making entry and exit decisions. Sutton (1997.a, p.52-53) notes the primary importance of the volatility of industry profits in affecting entry and exit decisions. Firms are assumed to use a forecasting equation to predict future profits. This filters out the systematic components and the standard deviation of the residuals - the unsystematic component measures profit uncertainty. ${ }^{11}$ We measure industry profitability per unit of sales, assuming that intermediate materials, energy and labor comprise the total variable costs. Our main measure of profitability is given by $\pi$ (M1 - see table below). ${ }^{12}$

\footnotetext{
${ }^{11}$ This notion of uncertainty is consistent with previous work; see, e.g., Aizenman and Marion (1997), Ghosal and Loungani (1996, 2000), Huizinga (1993) and Lensink, Bo and Sterken (2002). These studies use the standard deviation (or the conditional standard deviation) of some variable of interest as a measure of uncertainty.

${ }^{12}$ This is consistent with theoretical definition of short-run profits (Varian, 1992, Ch.2). Empirically, this is a commonly used measure; see Carlton and Perloff (1994, Ch.9), Domowitz et al. (1986, 1987), Geroski and Mueller (1990), Ghosal (2000) and Machin and Van Reenen (1993). Carlton and Perloff (p.334-343) and Schmalensee (1989) discuss alternate measures and their pitfalls. Our measure $\Pi$ does not control for capital costs, which are more important for measuring long-run profitability. As discussed by Carlton and Perloff and Schmalensee, quantifying capital costs is difficult due to problems related to valuing capital and assessing depreciation.
} 
Profitability Measures; Forecasting Specifications; Uncertainty Variable.

A. Profitability Measures.

(M1) $\pi=($ Sales Revenue-Variable Costs $) /($ Sales Revenue $)$

(M2) $\pi(d)=($ Sales Revenue-Variable Costs-Depreciation Expenditures $) /($ Sales Revenue $)$

\section{B. Forecasting Specification.}

(S1) $\pi_{\mathrm{i}, \mathrm{t}}=\alpha+\lambda_{\mathrm{j}} \sum_{\mathrm{j}} \pi_{\mathrm{i}, \mathrm{t}-\mathrm{j}}+\xi_{\mathrm{k}} \sum_{\mathrm{k}} \mathrm{SALES}_{\mathrm{i}, \mathrm{t}-\mathrm{k}}+\gamma_{\mathrm{m}} \sum_{\mathrm{m}} \mathrm{UN}_{\mathrm{t}-\mathrm{m}}+\epsilon_{\mathrm{i}, \mathrm{t}}$ Uncertainty measure: $\sigma(\pi: \mathrm{S} 1)$

$(\mathrm{S} 2) \pi_{\mathrm{i}, \mathrm{t}}=\alpha+\lambda_{\mathrm{j}} \sum_{\mathrm{j}} \pi_{\mathrm{i}, \mathrm{t}-\mathrm{j}}+\xi_{\mathrm{k}} \sum_{\mathrm{k}} \mathrm{SALES}_{\mathrm{i}, \mathrm{t}-\mathrm{k}}+\delta_{\mathrm{n}} \sum_{\mathrm{n}} \mathrm{FFR}_{\mathrm{t}-\mathrm{n}}+\tau_{\mathrm{p}} \sum_{\mathrm{p}} \mathrm{ENER}_{\mathrm{t}-\mathrm{p}}+\mathrm{v}_{\mathrm{i}, \mathrm{t}}$ Uncertainty measure: $\sigma(\pi: \mathrm{S} 2)$

(S3) $\pi_{\mathrm{i}, \mathrm{t}}=\alpha+\lambda_{\mathrm{j}} \sum_{\mathrm{j}} \pi_{\mathrm{i}, \mathrm{t}-\mathrm{j}}+\omega_{\mathrm{i}, \mathrm{t}}$

Uncertainty measure: $\sigma(\pi: \mathrm{S} 3)$

The benchmark profit forecasting specification S1 includes lagged values of $\pi$, industry-specific sales growth (SALES) and economy-wide unemployment rate (UN). The justification for such a specification is contained in the studies by Domowitz, Hubbard and Petersen (1986) and Machin and VanReenen (1993) which show the sensitivity of profit-margins to industry-specific and aggregate economic conditions. For each industry in our sample, we first estimate specification S1 using annual data over the entire sample period 1958-1994. ${ }^{13}$ The residuals represent the unsystematic components. The standard deviation of residuals, $\sigma(\pi: \mathbf{S 1})_{\mathrm{i}}$, is our primary measure of uncertainty. Table 3 presents the summary statistics on $\sigma(\pi: S 1)$ and Figure 1 plots the raw data on $\sigma($ Firms $)$ and $\sigma(\pi: S 1)$. Table 4 presents the correlation between $\sigma($ Firms $)$ and $\sigma(\pi: \mathrm{S} 1)$; the correlation is negative and marginally larger than those observed for sunk costs.. To check for robustness, we:

(1) Consider alternate specifications S2 and S3. The motivation for S2 is from the results in Ghosal (2000) where we replace the broad business cycle indicator, unemployment rate, by the federal funds rate (FFR) and energy price growth (ENERGY). Specification S3 is a basic AR(2) model; and

\footnotetext{
${ }^{13}$ We present some summary statistics from the regressions S1 estimated to measure uncertainty. Across the 266 industries, the mean Adjusted- $\mathrm{R}^{2}$ and the standard deviation of adjusted- $\mathrm{R}^{2}$ were 0.61 and 0.24 , respectively. The first-order serial correlation was typically low, with the cross-industry mean (std. dev across industries) being -0.019 (0.067). Overall, the fit of the industry regressions was good.
} 
(2) Construct an alternate measure of profitability $\pi(d)$ which accounts for depreciation expenditures. The data on industry-specific depreciation rates were collected for the Census years 1972, 1982 and 1992 (same as those used to create the DEPR sub-samples). We assumed that these data are representative for the entire sample period and constructed $\pi(d)$. We used $\pi(d)$ in conjunction with S1 to compute an alternate measure $\sigma[\pi(d)]$.

In Section 4.2 we report results for these additional checks and our broad inferences are not affected.

\subsection{Technology}

We use two measures of technological progress. The first measure is industry $\mathbf{R} \& \mathbf{D}$ intensity. The basic assumption being that industries with higher R\&D will show greater technological progress and costefficiency gains. Audretsch (1995, p.27-29) and Cohen and Levin (1989) highlight limitations linking R\&D expenditures to technological change and market opportunities. Given some of the criticisms, we construct a second measure: total factor productivity growth, TFP.

For a four-factor (capital stock, K; labor hours H; materials, M; and energy, E) production function, the basic Solow residual is: $\operatorname{TFP}(\mathbf{0})_{t}=\left[\Delta \mathrm{q}_{\mathrm{t}}-\left(\gamma_{\mathrm{k}_{\mathrm{t}}} \Delta \mathrm{k}_{\mathrm{t}}+\gamma_{\mathrm{ht}_{\mathrm{t}}} \Delta \mathrm{h}_{\mathrm{t}}+\gamma_{\mathrm{mt}} \Delta \mathrm{m}_{\mathrm{t}}+\gamma_{\mathrm{et}} \Delta \mathrm{e}_{\mathrm{t}}\right)\right]$, where $\mathrm{q}, \mathrm{k}, \mathrm{h}, \mathrm{m}$ and e are logarithms of output and the four inputs, and $\gamma$. the input share. The literature has shown that there can be significant deviation between true technological change and TFP( 0$)$. Inputs like capital have variable "utilization" over the business cycle, imparting a strong procyclical bias to TFP(0); see Burnside et al. (1995), Burnside (1996) and Basu (1996). Burnside et al. (1995) use electricity consumption to proxy utilization of capital and obtain a corrected Solow residual; other proxies have included total energy consumption and materials inputs. ${ }^{14}$ Following this literature, we construct a factor-utilizationadjusted technology residual TFP(1) (see data appendix for details). Table 3 presents the summary statics on R\&D and TFP(1) and Figures 3-4 plot the data. Table 4 presents the cross-industry sample

\footnotetext{
${ }^{14}$ The basic intuition is that these inputs (materials and energy) do not have a cyclical utilization (or "hoarding") component like capital and, therefore, are good proxies for the utilization of capital; e.g., assuming capital stock is constant, if the utilization of capital increases, then materials and energy usage will typically increase.
} 
correlations, which show a negative relationship between the measures of innovation and $\sigma($ Firms $)$ and $\sigma\left(\right.$ Estb). The relationship is a stronger negative for R\&D as compared to TFP(1). ${ }^{15}$

\subsection{Additional Control Variables}

After presenting our main results, we report results by incorporating additional control variables that may influence $\sigma$ (Firms) and $\sigma$ (Estb). First, we include industry advertising intensity, ADVT. Greater advertising intensity may have both entry-retarding as well as entry-enhancing effects (Kessides, 1986). The former may reduce entry due to advertising related sunk cost barriers and, consequently, exits will also be lower leading to lower $\sigma$ (Firms). The latter implies that a greater differentiated array of products may facilitate entry into "niche" market segments. The net effect appears to be ambiguous. Second, we include the industry's mean rate of growth over the sample period, GRS. Greater growth may facilitate entry resulting in increased $\sigma$ (Firms), but this effect is conditioned on underlying barriers to entry.

\section{Estimation}

Our cross-industry specification (1) is quadratic and includes both the technology variables (R\&D and TFP). The quadratic terms capture non-linearities in the relationships discussed in section 2 .

$$
\begin{gathered}
\sigma(\text { Firms })_{\mathrm{i}}=\alpha_{0}+\alpha_{1} \sigma(\pi: \mathrm{S} 1)_{\mathrm{i}}+\alpha_{2} \sigma(\pi: \mathrm{S} 1)_{\mathrm{i}}^{2}+\alpha_{3} \Phi(\mathrm{W})_{\mathrm{i}}+\alpha_{4} \Phi(\mathrm{W})_{\mathrm{i}}^{2}+\alpha_{5} \mathrm{R} \& \mathrm{D}_{\mathrm{i}}+\alpha_{6}{\mathrm{R} \& \mathrm{D}_{\mathrm{i}}^{2}+}+ \\
\alpha_{7} \operatorname{TFP}(1)_{\mathrm{i}}+\alpha_{8} \operatorname{TFP}(1)_{\mathrm{i}}^{2}+\mathrm{v}_{\mathrm{i}},
\end{gathered}
$$

where $i=1, \ldots, 266$ industries, $\sigma$ (Firms) is the standard deviation of the number of firms in an industry, $\sigma(\pi: \mathrm{S} 1)$ measures profit uncertainty, $\Phi(\mathrm{W})$ is the weighted-index of sunk capital costs, R\&D is research and development intensity, and TFP(1) is the cyclical-factor-utilization adjusted total factor productivity

\footnotetext{
${ }^{15}$ As we note in the appendix, construction of TFP measures poses several problems such as quality adjustment of inputs and treatment of the factor-shares coefficients. This in part may explain observations of negative TFP growth in the literature (or technological regress) and may have an impact on our estimated relationships.
} 
measure. To check the importance of non-linearities and the relative contributions of the two technology variables, we estimate (1) as well as the following stripped-down specifications:

(1) $\alpha_{2}=\alpha_{4}=\alpha_{6}=\alpha_{8}=0$ - our basic linear model which includes R\&D and TFP;

(2) $\alpha_{2}=\alpha_{4}=\alpha_{6}=\alpha_{8}=\alpha_{5}=0$ or $\alpha_{2}=\alpha_{4}=\alpha_{6}=\alpha_{8}=\alpha_{7}=0$ - linear model with R\&D or TFP;

(3) $\alpha_{6}=\alpha_{8}=0$ - quadratic in $\Phi$ and $\sigma(\pi: S 1)$ and linear effects for R\&D and TFP; and

(4) $\alpha_{7}=\alpha_{8}=0$ or $\alpha_{5}=\alpha_{6}=0$ - quadratic model with R\&D or TFP.

\subsection{Baseline Results}

We start by looking at the results in Table 5. First, an important comment about the reported numbers. Since the scale of the model variables differ enormously (see the mean values in Table 3), we present numbers where the estimated slope coefficient is multiplied by one-standard-deviation of the relevant variable. For example, the estimated coefficient of $\sigma(\pi: S 1)$ in column 1 was $-4,737$, and one-s.d. of $\sigma(\pi: S 1)$ is 0.0108 (rounded off to 0.011 in Table 3). Multiplying the two we get the reported number of -51 . One way to interpret this number is as follows. Suppose we start at the mean values of $\sigma($ Firms) and $\sigma(\pi:$ S1); i.e., 120.1 and 0.027 respectively (Table 3$)$. From this, a one-s.d. increase in $\sigma(\pi: \mathrm{S} 1)$ leads to a 51 point drop in $\sigma($ Firms). This represents a fairly large quantitative effect given the mean value of $\sigma($ Firms). We employ this procedure in all the subsequent tables to give the reader a clearer picture of the quantitative effects across the model variables and alternate specifications. ${ }^{16}$

For the linear specifications in the first three columns, we find that higher sunk costs, profit uncertainty and R\&D intensity lowers $\sigma$ (Firms). The sign of TFP effect is negative, but the coefficient is statistically insignificant whether we enter it individually or in combination with R\&D. The signs of the sunk cost and profit uncertainty effects are in the direction predicted by the theories summarized in section 2. We had noted that the sign of the technology effect is ambiguous in general. Our estimates for $R \& D$ and TFP reveal a negative effect, but it is significant only for R\&D intensity. In terms of

\footnotetext{
${ }^{16} \mathrm{We}$ do not calculate elasticities due to our main specifications being quadratic. Using the above procedure (along with Figures 5-12) allows us to see the impact of each of our model variables across specifications.
} 
quantitative effects, profit uncertainty has the largest effect followed by sunk costs and technology.

Next we move to the last column of Table 5 to examine whether there are non-linearities in the relationships. For both profit uncertainty and sunk cost, the linear terms are negative and the quadratic terms are positive. The estimated effects are highly significant statistically indicating marked nonlinearities and lend support to the predictions outlined in section 2. Regarding technology, both the R\&D and TFP effects show similar sign patterns, but only the R\&D effects are statistically significant. Figures 5-8 provide a graphical look at the estimated relationships. For example, Figure 5 presents the relationship between $\sigma($ Firms $)$ and $\sigma(\pi: \mathrm{S} 1)$ assuming all other variables are held at their mean values. The theory indicates that the negative effect of $\sigma(\pi: S 1)$ will be greater initially and the incremental effect diminishes as $\sigma(\pi: \mathrm{S} 1)$ gets larger; Figure 5 roughly lends support for this prediction. The fact that the graph shows increase in $\sigma($ Firms $)$ when $\sigma(\pi)$ is very high is a reflection of our using a smooth quadratic form to capture the effects. Examining Figure 1, which plots the raw data for $\sigma($ Firms $)$ and $\sigma(\pi)$, we don't find $\sigma($ Firms) increasing at very high $\sigma(\pi)$. Using a higher-order polynomial in sunk costs and profit uncertainty may remove this feature from the estimated relationships. To save space and take a quick look at this, we re-estimated equation (1) by augmenting it with cubic terms in $\sigma(\pi)$ and $\Phi(W)$. Figure 9 plots the estimated relationship. It is similar to Figure 5 except that we don't find $\sigma$ (Firms) really increasing when $\sigma(\pi)$ is very high. Similar results were obtained with other experiments using cubic specifications.

Table 6 presents the same set of results using $\sigma(E s t b)$ as the dependent variable. While there are some differences, the broad qualitative and quantitative effects are similar to those using $\sigma$ (Firms). One difference is that the TFP(1) effect has a higher level of statistical significance as compared to the $\sigma($ Firms) regressions. Figures 10-13 graph the relationships between $\sigma($ Estb) and the explanatory variables using the estimated coefficients. The broad picture is quite similar to those in Figures 5-8.

In Table 7 we report results using an alternate dependent variable: range(Firms) and range(Estb). The basic idea behind using range as an alternate variable is as follows. For example, if higher $\Phi(\mathrm{W})$ is likely to lower entry and, consequently, lower exits in equilibrium, then the observed range (max.-min.) 
of firms in the industry should be lower; i.e., a tighter range. While the quantitative effects cannot be directly compared with those presented in Tables 5-6, our the broad inferences remain intact. In Table 7 column 1, for example, we note a reduction of 139 in the range of firms for a one-s.d. increase in $\sigma(\pi: S 1)$. This represents a considerable quantitative effect given that the cross-industry mean value of range is 324 (see Table 1, row 1). Finally, in Table 8 we report results using the four sunk cost measures separately. For each measure, the sign pattern is the same as for the weighted sunk cost measure $\Phi(\mathrm{W})$ and the estimated effects are statistically significant. The quantitative effect varies across the different measures. Our broad conclusions are not altered by using the sunk costs measures individually.

We summarize our findings so far as follows:

(1) Higher profit uncertainty and sunk costs are associated with significantly lower firm and establishment volatility. The relationship is best characterized as non-linear in the manner predicted by the underlying theories discussed in section 2.

(2) The technology variables show mixed effects. Greater R\&D intensity is associated with lower firm and establishment volatility. The relationship appears best characterized as non-linear. The quantitative effect of R\&D on firm and establishment volatility is smaller than those of profit uncertainty and sunk costs. TFP growth effects show similar sign patterns to R\&D intensity, but the estimated effects are generally statistically insignificant and the quantitative effects are very small. As noted earlier and in the appendix, part of the problem may be related to difficulties in accurate measurement of TFP.

\section{Some Checks of Robustness}

For comparison, column A of Table 9 reproduces the results from the last column of Table 5. The other columns carry out the following experiments:

(1) In section 3.3 we noted alternate forecasting equations to measure uncertainty: $\sigma(\pi: \mathrm{S} 2)$ and $\sigma(\pi: \mathrm{S} 3)$. These results are reported in columns B and C;

(2) We considered an alternate measure of profitability $\sigma[\pi(d)]$ which accounts for depreciation expenditures and measuring uncertainty using this. These results are reported in column D; 
(3) In section 3.5 we discussed additional control variables for equation (1): advertising intensity and industry growth. These results appear in column E.

As is evident from Table 9, these checks for robustness do not alter our broad conclusions.

\subsection{Small versus Large Establishments}

In section 2.5 we noted that previous research shows that the vast majority of entrants and exiters are rather small compared to the typical incumbent. Thus we expect most of the entry/exit action and corresponding firm and establishment volatility to be generated in the small size group. As indicated in section 3.1, we have data on establishment size but not firm size. In Row 3 of Table 2, we presented data on the distribution of the ratio (Estb/Firms). This revealed that the median value is 1.12 establishments per firm; even at the $90^{\text {th }}$ percentile level, there are about 1.6 establishments per firm. Thus, we can assume rough correspondence between the size distribution of firms and establishments. Table 10 presents the results by establishment size group. The last column is for the largest size group; the sizes get smaller as we move left. The key observation is that the relationship between establishment volatility and sunk costs, profit uncertainty and technology is arising from the smaller establishment groups. For the larger group, the quantitative effects are tiny and the statistical significance and signs are mixed.

\section{Final Remarks}

Our study reveals interesting and economically meaningful effects of sunk capital costs, uncertainty about profits and technology on the volatility of the number of firms and establishments. Figures 5-13 display our key findings. Industries with greater sunk capital costs (Figures 6 and 11) and profit uncertainty (Figures 5 and 10) show lower volatility of firms and establishments. These relationships are non-linear in the sense that initial increases in sunk costs or profit uncertainty appear to have a relatively larger impact than subsequent increases. To put it differently, small amounts of sunk costs and uncertainty appear sufficient to generate noticeable hysteresis in entry/exit, reducing the variability of firms and establishments. This is consistent with the theoretical insights in Dixit (1989) and Dixit and 
Pindyck (1994). The results on technological change are mixed. Using R\&D intensity (Figures 7 and 12) we find that greater R\&D lowers firm and establishment volatility and the relationship is non-linear (qualitatively similar to those obtained for sunk costs and uncertainty). However, using total factor productive growth (Figures 8 and 13) as an alternate measure did not reveal much insight.

While our findings could be useful in several areas, we focus on potential implications for antitrust/competition policy. Our analysis was conducted using data for SIC 4-digit industries and we cannot make direct linkages to markets as defined in antitrust analysis which tend to be much more disaggregated and detailed. A similar analysis carried out using more disaggregated data may reveal additional insights. Here we draw some broad implications. The U.S. Department of Justice and Federal Trade Commission Merger Guidelines (1997) - henceforth, "Guidelines" - notes that the ultimate objective of merger analysis is to determine (Guidelines, p.3) "...whether the merger is likely to create or enhance market power or to facilitate its exercise." In evaluating this, the Guidelines contain a detailed analysis of entry. "Uncommitted entrants" are defined as those who are likely to (p.11) "...enter within one year and without the expenditure of significant sunk costs of entry and exit," where sunk costs are defined to include (p.12) “...investments in production facilities, technologies, marketing, $R \& D$, regulatory approvals and testing." In contrast, (p.26) “committed entry” is defined as “...new competition that requires expenditure of significant sunk costs of entry and exit," and the Guidelines (p.25-30) lay out a three-step methodology to assess whether committed entry would counteract a competitive effect of concern. The broad picture that emerges is a clear recognition of the role played by sunk costs in determining entry and the consequent evaluation of competitive effects. Our findings related to sunk costs can be interpreted at two levels. First, our estimates imply that sunk costs are likely to induce entry/exit hysteresis, validating the concerns laid out in the Guidelines. Second, and perhaps more importantly, the results appear to indicate that the presence of even small amounts of sunk costs seem sufficient to induce considerable hysteresis. This quantitative result further highlights the need to evaluate sunk costs carefully - even when they are small in magnitude. Our results on R\&D intensity, a variable explicitly mentioned in the Guidelines, appears to demonstrate similar importance. 
Our findings related to uncertainty about profits take on a somewhat newer dimension. Uncertainty is not explicitly mentioned as a factor that may have adverse effects on entry. The received theory (Dixit, 1989; Dixit and Pindyck, 1994) clearly recognizes uncertainty as a key determinant of entry and exit. Our empirical results emphasize the significance of this effect. In addition, we find that the quantitative effect of profit uncertainty is considerably larger than those of sunk capital costs or R\&D. At a broad brush, this calls for emphasis on uncertainty when evaluating entry and exit and competitive effects in antitrust analysis. 


\section{References}

Appelbaum, Elie, and Chin Lim. "Contestable Markets under Uncertainty," RAND Journal of Economics $16,1985,28-40$.

Audretsch, David. Innovation and Industry Evolution. Cambridge: MIT Press, 1995.

Basu, Susanto. “Procyclical Productivity: Increasing Returns or Cyclical Utilization?" Quarterly Journal of Economics 111, 1996, 719-751.

Baumol, William, John Panzar, and Robert Willig. Contestable Markets and the Theory of Industry Structure. San Diego: Harcourt Brace Jovanovich, 1982.

Burnside, Craig. "Production Function Regressions, Returns to Scale, and Externalities," Journal of Monetary Economics 37, 1996, 177-201.

Burnside, Craig, Martin Eichenbaum and Sergio Rebelo. "Capital Utilization and Returns to Scale," National Bureau of Economic Research Macroeconomics Annual, 1995, 67-119.

Caves, Richard, and Michael Porter. "From Entry Barriers to Mobility barriers," Quarterly Journal of Economics 9, 241-267.

Cohen, Wesley and Richard Levin. "Empirical Studies of Innovation and Market Structure" in Schmalensee, Richard and Robert Willig, ed., Handbook of Industrial Organization, Amsterdam: North Holland, (1989).

Cooley, Thomas and Vincenzo Quadrini. "Financial Markets and Firm Dynamics," American Economic Review, 2001, 1286-1310.

Cabral, Luis, and José Mata. "On the Evolution of the Firm Size Distribution: Facts and Theory," American Economic Review, 2003, forthcoming.

Davis, Steven, John Haltiwanger and Scott Schuh. Job Creation and Destruction. Cambridge: MIT Press, 1996.

Dixit, Avinash. "Role of Investment in Entry Deterrence," Economic Journal 90, 95-106.

Dixit, Avinash. "Entry and Exit Decisions under Uncertainty," Journal of Political Economy 97, 1989, 620-638.

Dixit, Avinash, and Robert Pindyck. Investment under Uncertainty. Princeton: Princeton University Press, 1996.

Domowitz, Ian, Glenn Hubbard and Bruce Petersen. "Business Cycles and the Relationship Between Concentration and Price-Cost Margins," RAND Journal of Economics 17, 1986, 1-17. 
Dunne, Timothy, Mark Roberts, and Larry Samuelson. "Patterns of entry and exit in U.S. manufacturing industries," RAND Journal of Economics 19, 1988, 495-515.

Fazzari, Steven, Glenn Hubbard and Bruce Petersen, "Financing Constraints and Corporate Investment." Brookings Papers on Economic Activity 1 (1988), 141-195.

Geroski, Paul, and Dennis Mueller. “The Persistence of Profits in Perspective," in Dennis Mueller (ed.), The Dynamics of Company Profits. Cambridge: Cambridge University Press, 1990.

Geroski, Paul, and Joachim Schwalbach. Entry and Market Contestability. Oxford: Blackwell, 1991.

Ghosal, Vivek. "The Impact of Uncertainty and Sunk Costs on Firm Survival and Industry Dynamics," Working Paper, Georgia Institute of Technology, 2002.

Ghosal, Vivek. "Product Market Competition and Industry Price-Cost Margin Fluctuations: Role of Energy Price and Monetary Changes," International Journal of Industrial Organization 18, 2000, 415 444.

Ghosal, Vivek and Prakash Loungani. "The Differential Impact of Uncertainty on Investment in Small and Large Businesses," The Review of Economics and Statistics 82, 2000, 338-343.

Ghosal, Vivek and Prakash Loungani. "Product Market Competition and the Impact of Price Uncertainty on Investment," Journal of Industrial Economics 44, 1996, 217-228.

Gort, Michael and Steven Klepper. "Time Paths in the Diffusion of Product Innovations," Economic Journal 92, 1982, 630-653.

Greenwald, Bruce and Joseph Stiglitz. "Macroeconomic Models with Equity and Credit Rationing," in Hubbard, R. Glenn. ed., Asymmetric Information, Corporate Finance, and Investment. Chicago: University of Chicago Press, 1990, 15-42.

Huizinga, John, "Inflation Uncertainty, Relative Price Uncertainty and Investment in U.S. Manufacturing industries," Journal of Money, Credit, and Banking 25, 1993, 521-549.

Jovanovic, Boyan. "Slection and Evolution of Industry," Econometrica 50, 1982, 649-670.

Jovanovic, Boyan and Glenn MacDonald. "The Life Cycle of a Competitive Industry," Journal of Political Economy 102, 1994, 322-347.

Kessides, Ioannis. "Market Concentration, Contestability and Sunk Costs," Review of Economics and Statistics 72, 1990, 614-622.

Kessides, Ioannis. "Advertising, Sunk Costs and Barriers to Entry," Review of Economics and Statistics $68,1986,84-95$. 
Lensink, Robert, Hong Bo, and Elmer Sterken. Investment, Capital Market Imperfections, and Uncertainty. Edward Elgar. 2001.

Pakes, Ariel, and Richard Ericson. "Empirical Implications of Alternate Models of Firm Dynamics," Journal of Economic Theory 79, 1998, 1-45.

Schmalensee, Richard, "Inter-Industry Studies of Structure and Performance," in Schmalensee, Richard and Robert Willig, ed., Handbook of Industrial Organization, Amsterdam: North Holland, (1989).

Shleifer, Andrei, and Robert Vishny. "Liquidation Values and Debt Capacity: A Market Equilibrium Approach,"Journal of Finance 47, 1992, 1343-1366.

Spence, Michael. "Entry, Capacity, Investment and Oligopolistic Pricing," Bell Journal of Investment 8, 534-544.

Spencer, Barbara, and James Brander. "Pre-Commitment and Flexibility: Applications to Oligopoly Theory," European Economic Review 36, 1992, 1601-1626.

Sutton, John. Sunk Costs and Market Structure. Cambridge: MIT Press, 1991.

Sutton, John. “Gibrat's Legacy,” Journal of Economic Literature 35, 1997(a), 40-59.

Sutton, John. Technology and Market Structure. Cambridge: MIT Press, 1997(b).

U.S. Department of Justice and Federal Trade Commission. Horizontal Merger Guidelines, 1997.

Williamson, Oliver. "Corporate Finance and Corporate Governance," Journal of Finance 43, 1988, 567591.

Winter, Sidney. "Schumpeterian Competition in Alternative Technological Regimes," Journal of Economic Behavior and Organization 5, 1984, 287-320. 


\section{Appendix A: Data Sources, Variables and Measurement.}

\section{A. Details.}

The table indicates the sources and years for which data are available. The industry data are at the U.S. SIC 4-digit (manufacturing) level (see Eric Bartlesman and Wayne Gray, "The Manufacturing Industry Productivity Database,” National Bureau of Economic Research, 1998).

\begin{tabular}{|l|l|l|}
\hline Variable & Source & Years Available \\
\hline $\begin{array}{l}\text { 4-digit industry time-series } \\
\text { data: sales, investment, capital } \\
\text { stock, costs, etc. }\end{array}$ & $\begin{array}{l}\text { Bartlesman and Gray (1998): } \\
\text { Annual Survey and Census of } \\
\text { Manufacturing. }\end{array}$ & $1958-1994$ \\
\hline $\begin{array}{l}\text { Number of establishments and } \\
\text { by size groups }\end{array}$ & Census of Manufacturing & $1963,67,72,77,82,87,92$. \\
\hline Number of firms & Census of Manufacturing & $1963,67,72,77,82,87,92$. \\
\hline Four-firm concentration & Census of Manufacturing & $1963,67,72,77,82,87,92$. \\
\hline Used capital expenditures & Census of Manufacturing & $1972,82,92$. \\
\hline Rental payments & Census of Manufacturing & $1972,82,92$. \\
\hline Depreciation payments & Census of Manufacturing & $1972,82,92$. \\
\hline R\&D Intensity & FTC Line-of-Business Data & $1975-1978$ \\
\hline Advertizing Intensity & FTC Line-of-Business Data & $1975-1978$ \\
\hline $\begin{array}{l}\text { Aggregate variables: } \\
\text { unemployment rate, federal } \\
\text { funds rate, energy prices. }\end{array}$ & $\begin{array}{l}\text { Economic Report of the } \\
\text { President. }\end{array}$ & $1958-1994$. \\
\hline
\end{tabular}

We use the FTC line-of-business data for R\&D and advertizing. The data are high quality and have been used in many studies, but unfortunately they are available only for a few years and were discontinued. In addition, some of the data are at the 3-digit, others at the 4-digit level. Where data were available only at the 3-digit level, all the underlying 4-digit industries were assumed to have the same values. I do not have access to SIC 4-digit data for R\&D and advertizing for all our industries over the 30 year period.

The following industries were excluded from the sample: (i) "Not elsewhere classified" since they do not correspond to well defined product markets; (ii) Industries that could not be matched properly over time due to SIC definitional changes; there were important definition changes in 1972 and 1987. For these industries, the industry time-series and other structural characteristics data are not comparable over the sample period; and (iii) Industries that had missing data on the industry structure, sunk cost, R\&D or advertising variables. The final sample contains 266 SIC 4-digit manufacturing industries. Given the above exclusions, the final sample contains industries that are well defined over the sample period and have data consistency. 


\section{B. Sunk Entry Capital Requirements.}

The construction here follows Sutton $(1991$, Ch.2). Let $\xi(>0)$ be defined as the setup cost or the minimal level of sunk cost that an entrant must incur, and S denote total industry sales (market size). Thus, in theory, $\xi / \mathrm{S}$ is the sunk cost relative to market size. In quantifying setup/sunk costs (Sutton 1991, Ch.4), he proposes a proxy that measures the "relative" level of setup costs across industries. Sunk costs are assumed to be proportional to the cost of constructing a single plant of minimum efficient scale (MES). Let $\Psi$ be a measure of MES, where $\Psi$ is the output of the median plant relative to industry output. Assume that the capital-sales ratio of the median firm is the same as the industry as a whole and denote industry capital-sales ratio by $\mathrm{K} / \mathrm{S}$. Then $(\xi / \mathrm{S})=\Psi(\mathrm{K} / \mathrm{S})$. If we can obtain a proxy for $\Psi$, and have data for industry $\mathrm{K}$ and $\mathrm{S}$, we can approximate $\xi / \mathrm{S}$. $\Psi$ is constructed using the distribution of plants within each SIC 4-digit industry according to employment size. Let ' $\mathrm{m}$ ' be the number of group sizes within the industry, and ' $n_{\mathrm{j}}$ ' and ' $\mathrm{S}_{\mathrm{j}}$ ' denote number of plants and total sales of the $\mathrm{j}^{\text {th }}$ size group $(\mathrm{j}=1, \ldots, \mathrm{m}$.). Let $\mathrm{Ms}_{\mathrm{j}}=\left(\mathrm{S}_{\mathrm{j}} / \mathrm{n}_{\mathrm{j}}\right) ; \mathrm{S}_{\mathrm{e}}=(1 / \mathrm{m}) \Sigma_{\mathrm{j}}\left(\mathrm{Ms}_{\mathrm{j}}\right)$; and $\mathrm{S}_{\mathrm{o}}=\Sigma_{\mathrm{j}} \mathrm{S}_{\mathrm{j}}$. Then $\Psi=\left(\mathrm{S}_{\mathrm{e}} / \mathrm{S}_{\mathrm{o}}\right)$. Using $\Psi$ and industry $\mathrm{K} / \mathrm{S}$, we obtain a proxy for $\xi / \mathrm{S}$. We label the term $\Psi(\mathrm{K} / \mathrm{S})$ as $\Phi(\mathbf{E K})$ (sunk costs - entry capital). As noted by Sutton (p.98), the cross-industry variation in $\Phi(\mathrm{EK})$ provides a rough proxy for the cross-industry variation in sunk costs. ${ }^{17}$ We obtained data to calculate $\Phi(\mathrm{EK})$ for the Census years, 1972, 1982 and 1992 (same time periods as for $\Phi(\mathrm{RE}), \Phi(\mathrm{US})$ and $\Phi(\mathrm{DE}))$.

\section{Factor-Utilization Adjusted Solow Residual.}

Burnside (1996) assumes that gross output $Q$ is a differentiable function of unobserved capital "services" $(S)$, labor hours $(H)$, materials $(M)$ and energy $(E)$ : $Q_{t}=Z_{t} F\left(S_{t}, H_{t}, M_{t}, E_{t}\right)$, where $Z$ represents exogenous technology shock. Assuming that $S$ is proportional to materials usage (Basu, 1996), or energy consumption (Burnside, 1996), and competitive factor markets, the log-linear approximation to the production function gives us the adjusted technology residual TFP(1):

(C.1) $\operatorname{TFP}(1)=\left[\Delta \mathrm{q}_{\mathrm{t}}-\left(\delta_{\mathrm{Kt}} \Delta \mathrm{e}_{\mathrm{t}}+\delta_{\mathrm{Ht}} \Delta \mathrm{h}_{\mathrm{t}}+\delta_{\mathrm{Mt}} \Delta \mathrm{m}_{\mathrm{t}}+\delta_{\mathrm{Et}} \Delta \mathrm{e}_{\mathrm{t}}\right)\right]$,

where lower case letters denote logarithms, $\delta$ is the share of the input in total revenue and $\Delta \mathrm{S}$ is replaced by $\Delta \mathrm{m}$ (Basu), or $\Delta \mathrm{e}$ (Burnside). In our experiments and empirical results, it did not matter whether we replaced $\Delta \mathrm{s}$ by $\Delta \mathrm{m}$ or $\Delta \mathrm{e}$. Given that $\Delta \mathrm{m}$ is a broad based measure of input usage, we report results with $\Delta \mathrm{m}$ as the proxy for $\Delta \mathrm{s}$. We use TFP(1) as our benchmark measure of technological change.

Finally, we note an important issue with TFP computations are the observations which generate negative TFP values, or technological regress. This problem cannot be eliminated completely and has been extensively discussed in the literature. Apart fro cyclicality adjustments noted above, some of the problems relate to input quality improvements and the treatment of factor-share coefficients. Regarding

\footnotetext{
${ }^{17}$ Sutton notes limitations of this measure. For example, (i) he assumes that the capital-output ratio of the median plant is representative of the entire industry, and this is unlikely to be the case; (ii) the book value of capital assets is used to compute the capital-sales ratio, but the book value underestimates the current replacement cost; (iii) the computation assumes that the age structure of capital does not vary across industries, and this is unrealistic. In addition, we note that $\Phi(\mathrm{K})$ is based on an estimate of the "median plant size". As discussed in Section 2.5, the typical entrant is very small compared to the typical incumbent, and it takes many years for new entrants to attain optimal scale. This implies that the median plant size overstates the entry capital requirements.
} 
the latter, in our construction we have assumed that the shares of labor, materials, capital, etc, are constant throughout the sample period. But if there is labor-saving innovation or innovation that increases materials intensity over the sample period, then the constructed TFP measures will be biased. Regarding cyclicality adjustments, Burnside et al.(1996) compute TFP(1) with annual data and find that it has lower volatility compared to $\operatorname{TFP}(0)$, and lower likelihood of technological regress, which is a desirable property. 


\begin{tabular}{|c|c|c|c|c|c|c|c|c|}
\hline & Mean & Min & $\operatorname{Max}$ & $10^{\text {th }}$ & $25^{\text {th }}$ & $50^{\text {th }}$ & $75^{\text {th }}$ & $90^{\text {th }}$ \\
\hline Firms & $\begin{array}{l}120.1 \\
{[324]}\end{array}$ & $\begin{array}{l}1.6 \\
{[4]} \\
\end{array}$ & $\begin{array}{l}1,313.7 \\
{[3,505]}\end{array}$ & $\begin{array}{c}8.9 \\
{[25]}\end{array}$ & $\begin{array}{l}19.7 \\
{[53]}\end{array}$ & $\begin{array}{r}54.6 \\
{[148]} \\
\end{array}$ & $\begin{array}{l}132.5 \\
{[361]}\end{array}$ & $\begin{array}{l}300.4 \\
{[782]}\end{array}$ \\
\hline Estb(all) & $\begin{array}{l}129.8 \\
{[349]}\end{array}$ & $\begin{array}{l}2.6 \\
{[7]}\end{array}$ & $\begin{array}{l}1,435.8 \\
{[3,873]}\end{array}$ & $\begin{array}{l}10.6 \\
{[26]}\end{array}$ & $\begin{array}{l}22.8 \\
{[63]}\end{array}$ & $\begin{array}{c}61.6 \\
{[164]}\end{array}$ & $\begin{array}{l}143.5 \\
{[377]}\end{array}$ & $\begin{array}{l}317.9 \\
{[812]}\end{array}$ \\
\hline $\operatorname{Estb}(\geq 500)$ & $\begin{array}{l}3.4 \\
{[9]}\end{array}$ & $\begin{array}{l}0.0 \\
{[0]}\end{array}$ & $\begin{array}{l}40.4 \\
{[98]}\end{array}$ & $\begin{array}{l}0.5 \\
{[1]}\end{array}$ & $\begin{array}{l}1.0 \\
{[3]}\end{array}$ & $\begin{array}{l}2.2 \\
{[6]}\end{array}$ & $\begin{array}{c}4.1 \\
{[11]}\end{array}$ & $\begin{array}{r}7.7 \\
{[21]}\end{array}$ \\
\hline $\operatorname{Estb}(<500)$ & $\begin{array}{l}129.2 \\
{[347]}\end{array}$ & $\begin{array}{l}3.3 \\
{[9]}\end{array}$ & $\begin{array}{l}1,431.4 \\
{[3,862]}\end{array}$ & $\begin{array}{l}11.1 \\
{[28]}\end{array}$ & $\begin{array}{l}22.7 \\
{[63]}\end{array}$ & $\begin{array}{c}61.3 \\
{[164]}\end{array}$ & $\begin{array}{l}142.9 \\
{[383]}\end{array}$ & $\begin{array}{l}305.9 \\
{[802]}\end{array}$ \\
\hline $\operatorname{Estb}(<250)$ & $\begin{array}{l}127.8 \\
{[344]}\end{array}$ & $\begin{array}{l}2.9 \\
{[8]}\end{array}$ & $\begin{array}{l}1,411.4 \\
{[3,817]}\end{array}$ & $\begin{array}{l}11.2 \\
{[30]}\end{array}$ & $\begin{array}{l}23.1 \\
{[63]}\end{array}$ & $\begin{array}{c}61.4 \\
{[160]}\end{array}$ & $\begin{array}{l}140.4 \\
{[387]}\end{array}$ & $\begin{array}{l}292.6 \\
{[793]}\end{array}$ \\
\hline Estb $(<50)$ & $\begin{array}{l}112.9 \\
{[302]}\end{array}$ & $\begin{array}{l}1.2 \\
{[3]}\end{array}$ & $\begin{array}{l}1,194.2 \\
{[3,235]}\end{array}$ & $\begin{array}{c}8.8 \\
{[23]}\end{array}$ & $\begin{array}{l}18.3 \\
{[48]}\end{array}$ & $\begin{array}{c}50.5 \\
{[138]}\end{array}$ & $\begin{array}{l}133.8 \\
{[351]}\end{array}$ & $\begin{array}{l}270.2 \\
{[754]}\end{array}$ \\
\hline Estb $(<20)$ & $\begin{array}{r}94.1 \\
{[252]}\end{array}$ & $\begin{array}{l}1.1 \\
{[3]}\end{array}$ & $\begin{array}{r}896.8 \\
{[2,430]}\end{array}$ & $\begin{array}{r}6.9 \\
{[19]}\end{array}$ & $\begin{array}{l}15.8 \\
{[45]}\end{array}$ & $\begin{array}{c}41.1 \\
{[109]}\end{array}$ & $\begin{array}{l}110.3 \\
{[302]}\end{array}$ & $\begin{array}{l}221.1 \\
{[580]}\end{array}$ \\
\hline
\end{tabular}

1. Data cover 266 SIC 4-digit manufacturing industries over the Census years 1963-92 (see data appendix). For each industry, we compute the standard deviation (s.d.) of the number of firms over the 7 Census years. This gives us 266 observations. The table presents the cross-industry summary statistics of these s.d.'s. For the typical industry, the s.d. of the number of firms was 120, ranging from (min) 1.6 to (max) 1,313. Similarly, we computed s.d.'s for the total number of establishments and by establishment size groups. Estb $(\geq 500)$ contains establishments with more than 500 employees - our "larger" establishment group. We have 5 "smaller" establishment groups defined by $<500,<250,<100,<50$ and $<20$ employees. Section 3.1 details these size groups. For the Estb $(\geq 500)$ group there are 15 industries with either (i) no establishments in this size group or (ii) have 1 or 2 establishments and there is no variation in these over the 7 Census years. Thus the standard deviation for these 15 industries is zero (see 'Min' column for the 'Estb $(\geq 500)$ ' row).

2. The numbers in square brackets [•] are the cross-industry summary statistics on the "range" ( $\max -\min )$ of the number of firms and establishments over the 7 Census years. For the typical industry, the range of the number of firms was 324; across industries, the range spanned a minimum of 4 to a maximum of 3,505. Similarly, we computed ranges for the total number of establishments and by establishment size groups. 
Table 2. Distribution of Firms and Establishments and by Size Group

\begin{tabular}{|l|l|l|l|l|l|l|l|}
\hline & & & \multicolumn{5}{|c|}{ Percentile Distribution } \\
\hline & Mean & s.d. & $10^{\text {th }}$ & $25^{\text {th }}$ & $50^{\text {th }}$ & $75^{\text {th }}$ & $90^{\text {th }}$ \\
\hline Estb(all) & 623 & 896 & 63 & 151 & 335 & 712 & 1565 \\
\hline Firms & 558 & 835 & 50 & 115 & 279 & 619 & 1386 \\
\hline$[$ Estb/Firms $]$ & 1.26 & 0.43 & 1.02 & 1.06 & 1.12 & 1.28 & 1.57 \\
\hline $\mathrm{s}[$ Estb $(\geq 500)]$ & 0.05 & 0.09 & 0.00 & 0.00 & 0.02 & 0.05 & 0.16 \\
\hline $\mathrm{s}[$ Estb $(<500)]$ & 0.95 & 0.09 & 0.84 & 0.94 & 0.98 & 0.99 & 0.99 \\
\hline $\mathrm{s}[$ Estb $<250)]$ & 0.89 & 0.13 & 0.71 & 0.86 & 0.94 & 0.98 & 0.99 \\
\hline $\mathrm{s}[$ Estb $(<100)]$ & 0.78 & 0.18 & 0.53 & 0.69 & 0.84 & 0.91 & 0.96 \\
\hline $\mathrm{s}[$ Estb $(<50)]$ & 0.67 & 0.19 & 0.40 & 0.56 & 0.70 & 0.82 & 0.91 \\
\hline $\mathrm{s}[$ Estb $(<20)]$ & 0.51 & 0.19 & 0.25 & 0.37 & 0.52 & 0.65 & 0.76 \\
\hline
\end{tabular}

1. Estb(all) and Firms are the total number of establishments and firms. For each industry we computed the ratio of the number of establishments per firm: the row [Estb/Firms] presents the cross-industry distribution of this ratio. For the typical ind ustry, there are 1.12 establishments per firm (the median value). The rows $\mathrm{s}[\operatorname{Estb}(\bullet)]$ show the distribution of the "share" of establishments in that size group. E.g., $\mathrm{s}[\mathrm{Estb}(<50)]$ is the ratio $[\mathrm{Estb}(<50) / \mathrm{Estb}(\mathrm{all})]$. For the typical industry in our sample, the $\mathrm{Estb}(<50)$ size group accounts for $67 \%$ of all establishments; and the Estb $(\geq 500)$ group accounts for only $5 \%$ of the total. (The numbers for the shares are rounded to the second decimal place; for $\mathrm{s}[\operatorname{Estb}(\geq 500)]$, the $10^{\text {th }}$ and $25^{\text {th }}$ percentile values are 0.0006 and 0.005 .) 
Table 3. Model Variables: Cross-Industry Summary Statistics.

\begin{tabular}{|c|c|c|c|c|c|c|c|}
\hline & & & \multicolumn{5}{|c|}{ Percentile Distribution } \\
\hline & Mean & s.d. & $10^{\text {th }}$ & $25^{\text {th }}$ & $50^{\text {th }}$ & $75^{\text {th }}$ & $90^{\text {th }}$ \\
\hline$\sigma($ Firms $)$ & 120.1 & 181.5 & 8.9 & 19.7 & 54.6 & 132.5 & 300.3 \\
\hline$\sigma($ Estb $)$ & 129.8 & 188.1 & 10.6 & 22.8 & 61.6 & 143.5 & 317.5 \\
\hline$\sigma(\pi: S 1)$ & 0.027 & 0.011 & 0.015 & 0.019 & 0.025 & 0.032 & 0.041 \\
\hline$\Phi(\mathrm{RE})$ & 90.1 & 94.6 & 15.1 & 28.8 & 55.5 & 107.5 & 232.6 \\
\hline$\Phi(\mathrm{US})$ & 21.5 & 37.8 & 6.9 & 8.4 & 12.6 & 18.3 & 32.7 \\
\hline$\Phi(\mathrm{DE})$ & 18.5 & 4.9 & 13.2 & 15.2 & 17.9 & 20.9 & 24.4 \\
\hline$\Phi(\mathrm{EK})$ & 0.014 & 0.060 & 0.001 & 0.003 & 0.005 & 0.012 & 0.024 \\
\hline$\Phi(\mathrm{W})$ & 32.5 & 29.6 & 10.4 & 14.6 & 22.2 & 37.4 & 69.9 \\
\hline $\mathrm{R} \& \mathrm{D}$ & 0.010 & 0.011 & 0.002 & 0.004 & 0.006 & 0.015 & 0.025 \\
\hline $\operatorname{TFP}(1)$ & 0.007 & 0.0115 & -0.004 & 0.0019 & 0.005 & 0.012 & 0.019 \\
\hline
\end{tabular}

1. Variable definitions: $\sigma($ Firms $)=$ standard deviation of the number of firms; $\sigma($ Estb $)=$ standard deviation of the number of establishments; $\sigma(\pi: \mathrm{S} 1)=$ profit uncertainty; $\Phi(\mathrm{RE})=$ sunk costs - rental intensity; $\Phi(\mathrm{US})=$ sunk costs - used capital intensity; $\Phi(\mathrm{DE})=$ sunk costs - depreciation; $\Phi(\mathrm{EK})=$ sunk costs - entry capital; $\Phi(\mathrm{W})=$ sunk costs - weighted index; R\&D=research and development intensity; TFP(1)=adjusted total factor productivity growth.

\begin{tabular}{|c|c|c|c|c|c|c|c|c|c|c|}
\hline$\sigma($ Firms $)$ & 1.00 & 0.99 & -0.34 & -0.29 & -0.14 & -0.26 & -0.11 & -0.30 & -0.16 & -0.07 \\
\hline$\sigma($ Estb $)$ & 0.99 & 1.00 & -0.35 & -0.29 & -0.15 & -0.25 & -0.11 & -0.29 & -0.16 & -0.09 \\
\hline
\end{tabular}


Table 5. Estimation Results.

Dependent Variable: $\sigma($ Firms).

\begin{tabular}{|c|c|c|c|c|c|c|c|}
\hline \multirow[b]{2}{*}{$\begin{array}{l}\sigma(\pi: \mathrm{S} 1) \\
\text { Profit Uncertainty }\end{array}$} & \multicolumn{3}{|c|}{ Linear Specification } & \multicolumn{4}{|c|}{ Quadratic Specification } \\
\hline & $\begin{array}{r}-51 \\
(0.001)\end{array}$ & $\begin{array}{r}-50 \\
(0.001)\end{array}$ & $\begin{array}{r}-51 \\
(0.001)\end{array}$ & $\begin{array}{r}-167 \\
(0.001)\end{array}$ & $\begin{array}{r}-157 \\
(0.001)\end{array}$ & $\begin{array}{r}-169 \\
(0.001)\end{array}$ & $\begin{array}{r}-158 \\
(0.001)\end{array}$ \\
\hline$\sigma(\pi: S 1)^{2}$ & - & - & - & $\begin{array}{r}123 \\
(0.001)\end{array}$ & $\begin{array}{r}114 \\
(0.001)\end{array}$ & $\begin{array}{r}125 \\
(0.001)\end{array}$ & $\begin{array}{r}113 \\
(0.001)\end{array}$ \\
\hline $\begin{array}{l}\Phi(\mathrm{W}) \\
\text { Sunk Cost - } \\
\text { Weighted Index }\end{array}$ & $\begin{array}{r}-33 \\
(0.002)\end{array}$ & $\begin{array}{r}-37 \\
(0.001)\end{array}$ & $\begin{array}{r}-33 \\
(0.003)\end{array}$ & $\begin{array}{r}-125 \\
(0.001)\end{array}$ & $\begin{array}{r}-112 \\
(0.001)\end{array}$ & $\begin{array}{r}-128 \\
(0.001)\end{array}$ & $\begin{array}{r}-111 \\
(0.001)\end{array}$ \\
\hline$\Phi(\mathrm{W})^{2}$ & - & - & - & $\begin{array}{r}87 \\
(0.001)\end{array}$ & $\begin{array}{r}87 \\
(0.003)\end{array}$ & $\begin{array}{r}87 \\
(0.001)\end{array}$ & $\begin{array}{r}87 \\
(0.003)\end{array}$ \\
\hline $\begin{array}{l}\mathrm{R} \& \mathrm{D} \\
R \& D \text { Intensity }\end{array}$ & $\begin{array}{r}-21 \\
(0.048)\end{array}$ & - & $\begin{array}{r}-20 \\
(0.055)\end{array}$ & $\begin{array}{r}-19 \\
(0.064)\end{array}$ & $\begin{array}{r}-79 \\
(0.001)\end{array}$ & - & $\begin{array}{r}-81 \\
(0.001)\end{array}$ \\
\hline $\mathrm{R} \& \mathrm{D}^{2}$ & - & - & - & - & $\begin{array}{r}66 \\
(0.008)\end{array}$ & - & $\begin{array}{r}66 \\
(0.008)\end{array}$ \\
\hline $\begin{array}{l}\text { TFP }(1) \\
\text { TFP Growth }\end{array}$ & - & $\begin{array}{r}-5 \\
(0.632)\end{array}$ & $\begin{array}{r}-1 \\
(0.907)\end{array}$ & $\begin{array}{r}2 \\
(0.851)\end{array}$ & - & $\begin{array}{r}-15 \\
(0.307)\end{array}$ & $\begin{array}{r}-14 \\
(0.323)\end{array}$ \\
\hline $\operatorname{TFP}(1)^{2}$ & - & - & - & - & - & $\begin{array}{r}18 \\
(0.202)\end{array}$ & $\begin{array}{r}21 \\
(0.129)\end{array}$ \\
\hline Intercept & $\begin{array}{r}303 \\
(0.001)\end{array}$ & $\begin{array}{r}288 \\
(0.001)\end{array}$ & $\begin{array}{r}303 \\
(0.001)\end{array}$ & $\begin{array}{r}512 \\
(0.001)\end{array}$ & $\begin{array}{r}521 \\
(0.001)\end{array}$ & $\begin{array}{r}505 \\
(0.001)\end{array}$ & $\begin{array}{r}526 \\
(0.001)\end{array}$ \\
\hline $\mathrm{R}^{2}$ & 0.1667 & 0.1548 & 0.1667 & 0.2417 & 0.2621 & 0.2364 & 0.2687 \\
\hline
\end{tabular}

1. The point estimates of the slope coefficients were multiplied by one-standard-deviation of the respective variable. This gives us an idea of the cross-industry quantitative effects for each variable.

2. $p$-values (two-tailed) from heterosced asticity-consistent standard errors are in parentheses. For $p$-values $<0.001$, it is indicated as 0.001 . The sample contains 266 industries (see data appendix). 
Table 6. Estimation Results.

Dependent Variable: $\sigma($ Estb).

\begin{tabular}{|c|c|c|c|c|c|c|c|}
\hline & \multicolumn{3}{|c|}{ Linear Specification } & \multicolumn{4}{|c|}{ Quadratic Specification } \\
\hline $\begin{array}{l}\sigma(\pi: \mathrm{S} 1) \\
\text { Profit Uncertainty }\end{array}$ & $\begin{array}{r}-55 \\
(0.001)\end{array}$ & $\begin{array}{r}-54 \\
(0.001)\end{array}$ & $\begin{array}{r}-55 \\
(0.001)\end{array}$ & $\begin{array}{r}-176 \\
(0.001)\end{array}$ & $\begin{array}{r}-168 \\
(0.001)\end{array}$ & $\begin{array}{r}-178 \\
(0.001)\end{array}$ & $\begin{array}{r}-167 \\
(0.001)\end{array}$ \\
\hline$\sigma(\pi: S 1)^{2}$ & - & - & - & $\begin{array}{r}128 \\
(0.001)\end{array}$ & $\begin{array}{r}121 \\
(0.001)\end{array}$ & $\begin{array}{r}129 \\
(0.001)\end{array}$ & $\begin{array}{r}118 \\
(0.001)\end{array}$ \\
\hline $\begin{array}{l}\Phi(\mathrm{W}) \\
\text { Sunk Cost - } \\
\text { Weighted Index }\end{array}$ & $\begin{array}{r}-34 \\
(0.003)\end{array}$ & $\begin{array}{r}-38 \\
(0.001)\end{array}$ & $\begin{array}{r}-33 \\
(0.004)\end{array}$ & $\begin{array}{r}-127 \\
(0.001)\end{array}$ & $\begin{array}{r}-114 \\
(0.001)\end{array}$ & $\begin{array}{r}-129 \\
(0.001)\end{array}$ & $\begin{array}{r}-112 \\
(0.001)\end{array}$ \\
\hline$\Phi(\mathrm{W})^{2}$ & - & - & - & $\begin{array}{r}87 \\
(0.001)\end{array}$ & $\begin{array}{r}87 \\
(0.004)\end{array}$ & $\begin{array}{r}87 \\
(0.001)\end{array}$ & $\begin{array}{r}87 \\
(0.003)\end{array}$ \\
\hline $\begin{array}{l}\mathrm{R} \& \mathrm{D} \\
R \& D \text { Intensity }\end{array}$ & $\begin{array}{r}-22 \\
(0.045)\end{array}$ & - & $\begin{array}{r}-21 \\
(0.055)\end{array}$ & $\begin{array}{r}-19 \\
(0.065)\end{array}$ & $\begin{array}{r}-81 \\
(0.002)\end{array}$ & - & $\begin{array}{r}-83 \\
(0.001)\end{array}$ \\
\hline $\mathrm{R} \& \mathrm{D}^{2}$ & - & - & - & - & $\begin{array}{r}68 \\
(0.010)\end{array}$ & - & $\begin{array}{r}67 \\
(0.010)\end{array}$ \\
\hline $\begin{array}{l}\text { TFP(1) } \\
\text { TFP Growth }\end{array}$ & - & $\begin{array}{r}-8 \\
(0.431)\end{array}$ & $\begin{array}{r}-5 \\
(0.673)\end{array}$ & $\begin{array}{r}-1 \\
(0.906)\end{array}$ & - & $\begin{array}{r}-24 \\
(0.109)\end{array}$ & $\begin{array}{r}-23 \\
(0.115)\end{array}$ \\
\hline $\operatorname{TFP}(1)^{2}$ & - & - & - & - & - & $\begin{array}{r}26 \\
(0.075)\end{array}$ & $\begin{array}{r}29 \\
(0.042)\end{array}$ \\
\hline Intercept & $\begin{array}{r}324 \\
(0.001)\end{array}$ & $\begin{array}{r}310 \\
(0.001)\end{array}$ & $\begin{array}{r}326 \\
(0.001)\end{array}$ & $\begin{array}{r}542 \\
(0.001)\end{array}$ & $\begin{array}{r}551 \\
(0.001)\end{array}$ & $\begin{array}{r}536 \\
(0.001)\end{array}$ & $\begin{array}{r}558 \\
(0.001)\end{array}$ \\
\hline $\mathrm{R}^{2}$ & 0.1730 & 0.1619 & 0.1736 & 0.2473 & 0.2663 & 0.2466 & 0.2781 \\
\hline
\end{tabular}

See Table 5. 
Table 7. Estimation Results.

Alternate Dependent Variable: "Range".

\begin{tabular}{|c|c|c|c|c|}
\hline & \multicolumn{2}{|c|}{ Range(Firms) } & \multicolumn{2}{|c|}{ Range(Estb) } \\
\hline & Linear & Quadratic & Linear & Quadratic \\
\hline $\begin{array}{l}\sigma(\pi: \mathrm{S} 1) \\
\text { Profit Uncertainty }\end{array}$ & $\begin{array}{r}-139 \\
(0.001)\end{array}$ & $\begin{array}{r}-431 \\
(0.001)\end{array}$ & $\begin{array}{r}-149 \\
(0.001)\end{array}$ & $\begin{array}{r}-450 \\
(0.001)\end{array}$ \\
\hline$\sigma(\pi: S 1)^{2}$ & - & $\begin{array}{r}309 \\
(0.001)\end{array}$ & - & $\begin{array}{r}317 \\
(0.001)\end{array}$ \\
\hline $\begin{array}{l}\Phi(\mathrm{W}) \\
\text { Sunk Cost - } \\
\text { Weighted Index }\end{array}$ & $\begin{array}{r}-91 \\
(0.003)\end{array}$ & $\begin{array}{r}-305 \\
(0.001)\end{array}$ & $\begin{array}{r}-91 \\
(0.004)\end{array}$ & $\begin{array}{r}-305 \\
(0.001)\end{array}$ \\
\hline$\Phi(\mathrm{W})^{2}$ & - & $\begin{array}{r}223 \\
(0.003)\end{array}$ & - & $\begin{array}{r}228 \\
(0.003)\end{array}$ \\
\hline $\begin{array}{l}\mathrm{R} \& \mathrm{D} \\
R \& D \text { Intensity }\end{array}$ & $\begin{array}{r}-59 \\
(0.042)\end{array}$ & $\begin{array}{r}-222 \\
(0.001)\end{array}$ & $\begin{array}{r}-61 \\
(0.039)\end{array}$ & $\begin{array}{r}-228 \\
(0.001)\end{array}$ \\
\hline $\mathrm{R} \& \mathrm{D}^{2}$ & - & $\begin{array}{r}181 \\
(0.008)\end{array}$ & - & $\begin{array}{r}180 \\
(0.009)\end{array}$ \\
\hline $\begin{array}{l}\text { TFP(1) } \\
\text { TFP Growth }\end{array}$ & $\begin{array}{r}-0.8 \\
(0.977)\end{array}$ & $\begin{array}{r}-26 \\
(0.509)\end{array}$ & $\begin{array}{r}-9 \\
(0.750)\end{array}$ & $\begin{array}{r}-52 \\
(0.194)\end{array}$ \\
\hline $\operatorname{TFP}(1)^{2}$ & - & $\begin{array}{r}46 \\
(0.229)\end{array}$ & - & $\begin{array}{r}68 \\
(0.080)\end{array}$ \\
\hline Intercept & $\begin{array}{r}824 \\
(0.001)\end{array}$ & $\begin{array}{r}1,431 \\
(0.001)\end{array}$ & $\begin{array}{r}882 \\
(0.001)\end{array}$ & $\begin{array}{r}1,506 \\
(0.001)\end{array}$ \\
\hline $\mathrm{R}^{2}$ & 0.1673 & 0.2672 & 0.1760 & 0.2779 \\
\hline
\end{tabular}

See Table 5 . 
Table 8. Individual Sunk Cost Measures. Dependent Variable: $\sigma($ Firms).

\begin{tabular}{|c|c|c|c|c|}
\hline $\begin{array}{l}\sigma(\pi: \mathrm{S} 1) \\
\text { Profit Uncertainty }\end{array}$ & $\begin{array}{r}-155 \\
(0.001)\end{array}$ & $\begin{array}{r}-173 \\
(0.001)\end{array}$ & $\begin{array}{r}-154 \\
(0.001)\end{array}$ & $\begin{array}{r}-158 \\
(0.001)\end{array}$ \\
\hline$\sigma(\pi: S 1)^{2}$ & $\begin{array}{r}108 \\
(0.001)\end{array}$ & $\begin{array}{r}121 \\
(0.001)\end{array}$ & $\begin{array}{r}106 \\
(0.002)\end{array}$ & $\begin{array}{r}113 \\
(0.001)\end{array}$ \\
\hline $\begin{array}{l}\Phi(\mathrm{RE}) \\
\text { Sunk Costs - } \\
\text { Rental Intensity }\end{array}$ & $\begin{array}{r}-118 \\
(0.001)\end{array}$ & - & - & - \\
\hline$\Phi(\mathrm{RE})^{2}$ & $\begin{array}{r}90 \\
(0.002)\end{array}$ & - & - & - \\
\hline $\begin{array}{l}\Phi(\mathrm{US}) \\
\text { Sunk Costs - } \\
\text { Used Intensity }\end{array}$ & - & $\begin{array}{r}-67 \\
(0.037)\end{array}$ & - & - \\
\hline$\Phi(\mathrm{US})^{2}$ & - & $\begin{array}{r}57 \\
(0.071)\end{array}$ & - & - \\
\hline $\begin{array}{l}\Phi(\mathrm{DE}) \\
\text { Sunk Costs - } \\
\text { Depreciation }\end{array}$ & - & - & $\begin{array}{r}-165 \\
(0.001)\end{array}$ & - \\
\hline$\Phi(\mathrm{DE})^{2}$ & - & - & $\begin{array}{r}138 \\
(0.007)\end{array}$ & - \\
\hline $\begin{array}{l}\Phi(\mathrm{EK}) \\
\text { Sunk Costs - } \\
\text { Entry Capital }\end{array}$ & - & - & - & $\begin{array}{r}-113 \\
(0.041)\end{array}$ \\
\hline$\Phi(\mathrm{EK})^{2}$ & - & - & - & $\begin{array}{r}111 \\
(0.036)\end{array}$ \\
\hline $\begin{array}{l}\mathrm{R} \& \mathrm{D} \\
R \& D \text { Intensity }\end{array}$ & $\begin{array}{r}-82 \\
(0.001)\end{array}$ & $\begin{array}{r}-90 \\
(0.001)\end{array}$ & $\begin{array}{r}-95 \\
(0.001)\end{array}$ & $\begin{array}{r}-89 \\
(0.001)\end{array}$ \\
\hline $\mathrm{R} \& \mathrm{D}^{2}$ & $\begin{array}{r}69 \\
(0.004)\end{array}$ & $\begin{array}{r}72 \\
(0.004)\end{array}$ & $\begin{array}{r}77 \\
(0.002)\end{array}$ & $\begin{array}{r}69 \\
(0.006)\end{array}$ \\
\hline $\begin{array}{l}\text { TFP(1) } \\
\text { TFP Growth }\end{array}$ & $\begin{array}{r}-17 \\
(0.237)\end{array}$ & $\begin{array}{r}-16 \\
(0.270)\end{array}$ & $\begin{array}{r}-17 \\
(0.237)\end{array}$ & $\begin{array}{r}-16 \\
(0.281)\end{array}$ \\
\hline $\operatorname{TFP}(1)^{2}$ & $\begin{array}{r}23 \\
(0.096)\end{array}$ & $\begin{array}{r}23 \\
(0.1039)\end{array}$ & $\begin{array}{r}15 \\
(0.301)\end{array}$ & $\begin{array}{r}23 \\
(0.108)\end{array}$ \\
\hline Intercept & $\begin{array}{r}512 \\
(0.001)\end{array}$ & $\begin{array}{r}504 \\
(0.001)\end{array}$ & $\begin{array}{r}835 \\
(0.001)\end{array}$ & $\begin{array}{r}465 \\
(0.001)\end{array}$ \\
\hline $\mathrm{R}^{2}$ & 0.2711 & 0.2268 & 0.2585 & 0.2262 \\
\hline
\end{tabular}

See Table 5. 
Table 9. Some Checks of Robustness. Dependent Variable: $\sigma($ Firms).

\begin{tabular}{|c|c|c|c|c|c|}
\hline & $\begin{array}{l}\text { A: Baseline } \\
\text { Table } 5 \text { - last } \\
\text { column }\end{array}$ & $\begin{array}{l}\text { B: Uncertainty } \\
\sigma(\pi: S 2)\end{array}$ & $\begin{array}{l}C: \text { Uncertainty } \\
\sigma(\pi: S 3)\end{array}$ & $\begin{array}{l}\text { D: Profitability } \\
\sigma[\pi(d)]\end{array}$ & $\begin{array}{l}\text { E: ADVT and } \\
\text { GRS }\end{array}$ \\
\hline $\begin{array}{l}\sigma(\bullet) \\
\text { Profit Uncertainty }\end{array}$ & $\begin{array}{r}-158 \\
(0.001)\end{array}$ & $\begin{array}{r}-159 \\
(0.001)\end{array}$ & $\begin{array}{r}-160 \\
(0.001)\end{array}$ & $\begin{array}{r}-153 \\
(0.001)\end{array}$ & $\begin{array}{r}-161 \\
(0.001)\end{array}$ \\
\hline$\sigma(\bullet)^{2}$ & $\begin{array}{r}113 \\
(0.001)\end{array}$ & $\begin{array}{r}113 \\
(0.001)\end{array}$ & $\begin{array}{r}112 \\
(0.001)\end{array}$ & $\begin{array}{r}114 \\
(0.001)\end{array}$ & $\begin{array}{r}111 \\
(0.001)\end{array}$ \\
\hline $\begin{array}{l}\Phi(\mathrm{W}) \\
\text { Sunk Cost - } \\
\text { Weighted Index }\end{array}$ & $\begin{array}{r}-111 \\
(0.001)\end{array}$ & $\begin{array}{r}-115 \\
(0.001)\end{array}$ & $\begin{array}{r}-112 \\
(0.001)\end{array}$ & $\begin{array}{r}-108 \\
(0.001)\end{array}$ & $\begin{array}{r}-115 \\
(0.001)\end{array}$ \\
\hline$\Phi(\mathrm{W})^{2}$ & $\begin{array}{r}87 \\
(0.003)\end{array}$ & $\begin{array}{r}87 \\
(0.001)\end{array}$ & $\begin{array}{r}87 \\
(0.002)\end{array}$ & $\begin{array}{r}87 \\
(0.002)\end{array}$ & $\begin{array}{r}87 \\
(0.002)\end{array}$ \\
\hline $\begin{array}{l}\mathrm{R} \& \mathrm{D} \\
R \& D \text { Intensity }\end{array}$ & $\begin{array}{r}-81 \\
(0.001)\end{array}$ & $\begin{array}{r}-82 \\
(0.001)\end{array}$ & $\begin{array}{r}-81 \\
(0.001)\end{array}$ & $\begin{array}{r}-79 \\
(0.002)\end{array}$ & $\begin{array}{r}-81 \\
(0.001)\end{array}$ \\
\hline$R \& D^{2}$ & $\begin{array}{r}66 \\
(0.008)\end{array}$ & $\begin{array}{r}66 \\
(0.008)\end{array}$ & $\begin{array}{r}65 \\
(0.008)\end{array}$ & $\begin{array}{r}65 \\
(0.009)\end{array}$ & $\begin{array}{r}67 \\
(0.008)\end{array}$ \\
\hline $\begin{array}{l}\text { TFP }(1) \\
\text { TFP Growth }\end{array}$ & $\begin{array}{r}-14 \\
(0.323)\end{array}$ & $\begin{array}{r}-14 \\
(0.318)\end{array}$ & $\begin{array}{r}-14 \\
(0.323)\end{array}$ & $\begin{array}{r}-16 \\
(0.282)\end{array}$ & $\begin{array}{r}-12 \\
(0.438)\end{array}$ \\
\hline $\operatorname{TFP}(1)^{2}$ & $\begin{array}{r}21 \\
(0.129)\end{array}$ & $\begin{array}{r}21 \\
(0.134)\end{array}$ & $\begin{array}{r}22 \\
(0.129)\end{array}$ & $\begin{array}{r}24 \\
(0.094)\end{array}$ & $\begin{array}{r}22 \\
(0.118)\end{array}$ \\
\hline $\begin{array}{l}\text { ADVT } \\
\text { Advertising } \\
\text { Intensity }\end{array}$ & - & - & & - & $\begin{array}{r}-2 \\
(0.827)\end{array}$ \\
\hline $\begin{array}{l}\text { GRS } \\
\text { Sales Growth }\end{array}$ & - & - & & - & $\begin{array}{r}-7 \\
(0.517)\end{array}$ \\
\hline Intercept & $\begin{array}{r}526 \\
(0.001)\end{array}$ & $\begin{array}{r}531 \\
(0.001)\end{array}$ & $\begin{array}{r}531 \\
(0.001) \\
\end{array}$ & $\begin{array}{r}511 \\
(0.001)\end{array}$ & $\begin{array}{r}542 \\
(0.001)\end{array}$ \\
\hline $\mathrm{R}^{2}$ & 0.2687 & 0.2690 & 0.2709 & 0.2642 & 0.2701 \\
\hline
\end{tabular}

For comparison, column A reproduces the last column from Table 5. For columns B, C and D see section 3.3: B and C use uncertainty measures $\sigma(\pi: \mathrm{S} 2)$ and $\sigma(\pi: \mathrm{S} 3)$; and D uses an alternate profitability measure $\pi(\mathrm{d})$ to construct the uncertainty measure $\sigma[\pi(\mathrm{d})]$. Column E uses the specification in column A but augments it with the advertisingintensity (ADVT) and industry growth (GRS) variables. See Table 5 for other details. 
Table 10. Estimates by Establishment Size Class.

Dependent variable: $\sigma($ Estb •)

\begin{tabular}{|c|c|c|c|c|c|c|}
\hline & Estb $<20$ & Estb $<50$ & Estb $<100$ & Estb $<250$ & Estb $<500$ & Estb $\geq 500$ \\
\hline $\begin{array}{l}\sigma(\pi) \\
\text { Profit Uncertainty }\end{array}$ & $\begin{array}{r}-119 \\
(0.001)\end{array}$ & $\begin{array}{r}-147 \\
(0.001)\end{array}$ & $\begin{array}{r}-159 \\
(0.001)\end{array}$ & $\begin{array}{r}-166 \\
(0.001)\end{array}$ & $\begin{array}{r}-167 \\
(0.001)\end{array}$ & $\begin{array}{r}-2 \\
(0.008)\end{array}$ \\
\hline$\sigma(\pi)^{2}$ & $\begin{array}{r}84 \\
(0.002)\end{array}$ & $\begin{array}{r}104 \\
(0.001)\end{array}$ & $\begin{array}{r}112 \\
(0.001)\end{array}$ & $\begin{array}{r}118 \\
(0.001)\end{array}$ & $\begin{array}{r}118 \\
(0.001)\end{array}$ & $\begin{array}{r}1 \\
(0.163)\end{array}$ \\
\hline $\begin{array}{l}\Phi(\mathrm{W}) \\
\text { Sunk Cost - } \\
\text { Weighted Index }\end{array}$ & $\begin{array}{r}-91 \\
(0.001)\end{array}$ & $\begin{array}{r}-105 \\
(0.001)\end{array}$ & $\begin{array}{r}-111 \\
(0.001)\end{array}$ & $\begin{array}{r}-113 \\
(0.001)\end{array}$ & $\begin{array}{r}-113 \\
(0.001)\end{array}$ & $\begin{array}{r}3 \\
(0.001)\end{array}$ \\
\hline$\Phi(\mathrm{W})^{2}$ & $\begin{array}{r}87 \\
(0.002)\end{array}$ & $\begin{array}{r}87 \\
(0.002)\end{array}$ & $\begin{array}{r}87 \\
(0.002)\end{array}$ & $\begin{array}{r}87 \\
(0.003)\end{array}$ & $\begin{array}{r}87 \\
(0.003)\end{array}$ & $\begin{array}{r}-2 \\
(0.001)\end{array}$ \\
\hline $\begin{array}{l}\mathrm{R} \& \mathrm{D} \\
R \& D \text { Intensity }\end{array}$ & $\begin{array}{r}-59 \\
(0.003)\end{array}$ & $\begin{array}{r}-73 \\
(0.002)\end{array}$ & $\begin{array}{r}-79 \\
(0.001)\end{array}$ & $\begin{array}{r}-83 \\
(0.001)\end{array}$ & $\begin{array}{r}-83 \\
(0.001)\end{array}$ & $\begin{array}{r}0.1 \\
(0.878)\end{array}$ \\
\hline $\mathrm{R} \& \mathrm{D}^{2}$ & $\begin{array}{r}47 \\
(0.016)\end{array}$ & $\begin{array}{r}59 \\
(0.011)\end{array}$ & $\begin{array}{r}64 \\
(0.010)\end{array}$ & $\begin{array}{r}67 \\
(0.008)\end{array}$ & $\begin{array}{r}66 \\
(0.009)\end{array}$ & $\begin{array}{r}0.3 \\
(0.654)\end{array}$ \\
\hline $\begin{array}{l}\text { TFP }(1) \\
\text { TFP Growth }\end{array}$ & $\begin{array}{r}-15 \\
(0.186)\end{array}$ & $\begin{array}{r}-20 \\
(0.127)\end{array}$ & $\begin{array}{r}-22 \\
(0.117)\end{array}$ & $\begin{array}{r}-23 \\
(0.124)\end{array}$ & $\begin{array}{r}-23 \\
(0.123)\end{array}$ & $\begin{array}{r}-0.7 \\
(0.051)\end{array}$ \\
\hline $\operatorname{TFP}(1)^{2}$ & $\begin{array}{r}18 \\
(0.105)\end{array}$ & $\begin{array}{r}23 \\
(0.074)\end{array}$ & $\begin{array}{r}25 \\
(0.066)\end{array}$ & $\begin{array}{r}27 \\
(0.061)\end{array}$ & $\begin{array}{r}28 \\
(0.052)\end{array}$ & $\begin{array}{r}1.3 \\
(0.001)\end{array}$ \\
\hline Intercept & $\begin{array}{r}406 \\
(0.001)\end{array}$ & $\begin{array}{r}495 \\
(0.001)\end{array}$ & $\begin{array}{r}532 \\
(0.001)\end{array}$ & $\begin{array}{r}555 \\
(0.001)\end{array}$ & $\begin{array}{r}558 \\
(0.001)\end{array}$ & $\begin{array}{r}548 \\
(0.001)\end{array}$ \\
\hline $\mathrm{R}^{2}$ & 0.2609 & 0.2737 & 0.2784 & 0.2804 & 0.2800 & 0.1691 \\
\hline
\end{tabular}

See Table 5. 

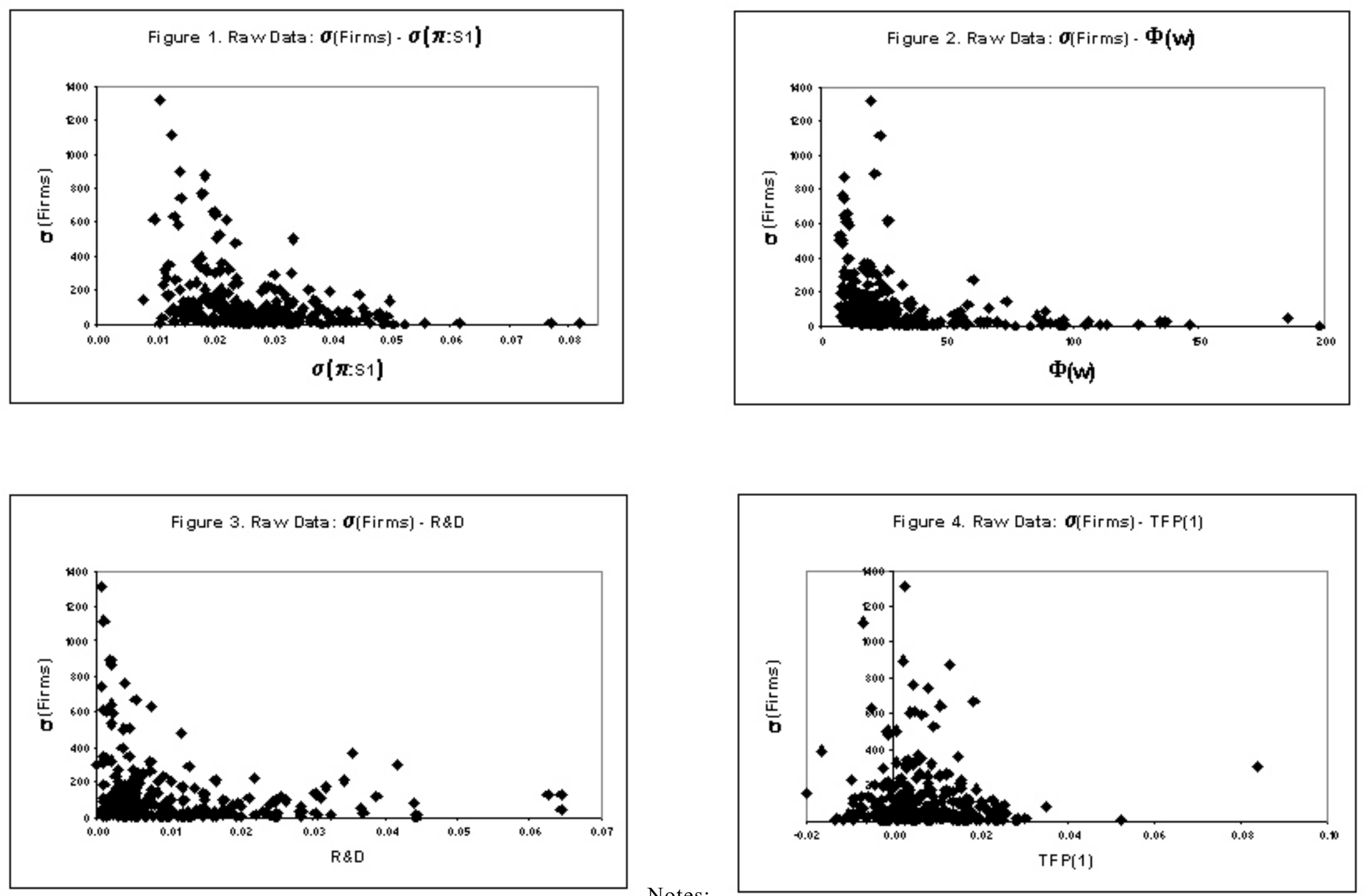

$\sigma($ Firms $)$ is the standard deviation of the number of firms; $\sigma(\pi: S 1)$ is profit

uncertainty; $\Phi(\mathrm{W})$ is the weighted index of sunk costs; R\&D is research and development intensity; and TFP(1) is the factor-utilization-adjusted total factor productivity growth. 

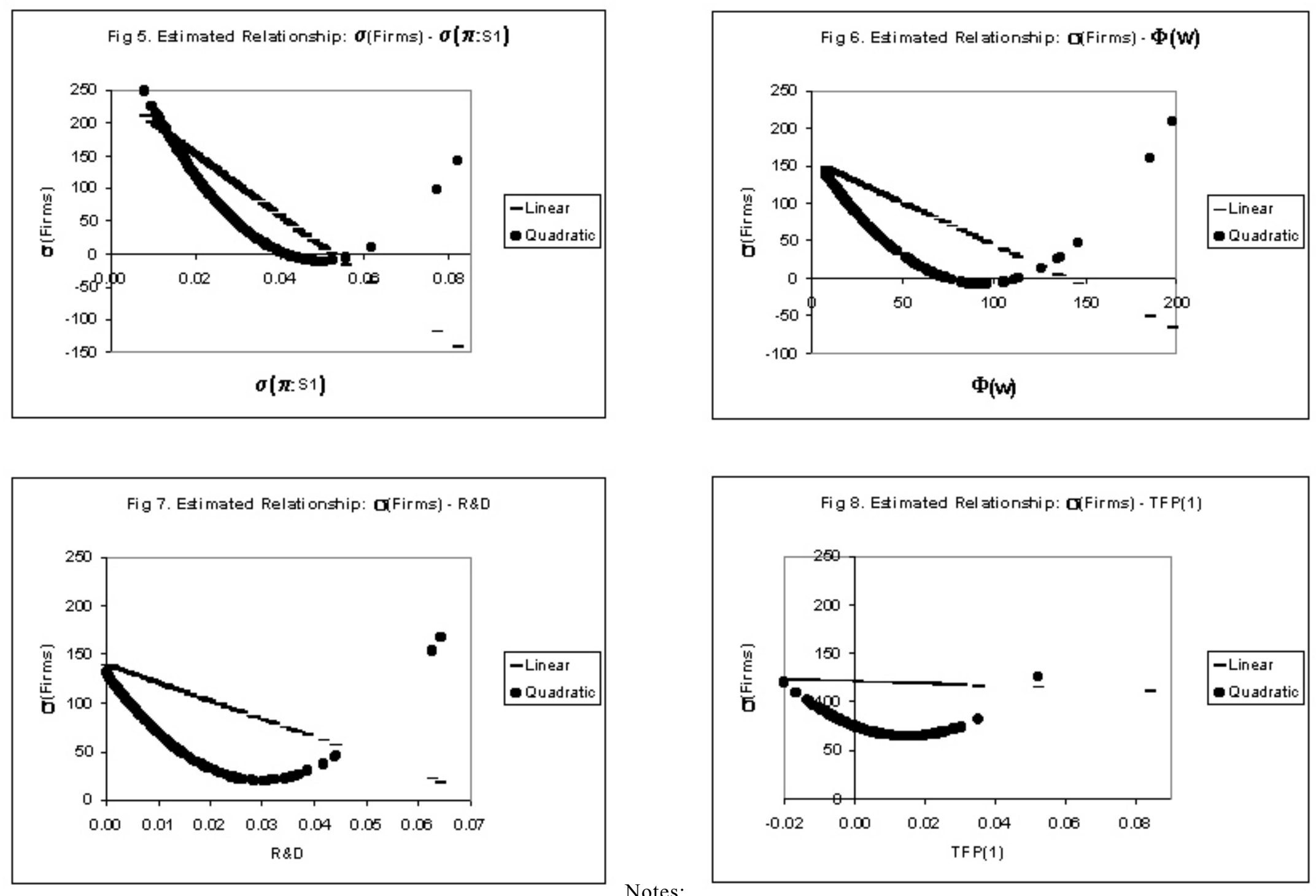

Figure 5, for example, presents the relationship between $\sigma($ Firms $)$ and $\sigma(\pi: \mathrm{S} 1)$ assuming all other variables are held at their mean values; similarly for Figures 6-8. See notes to Figures 1-4 for variables definitions. 


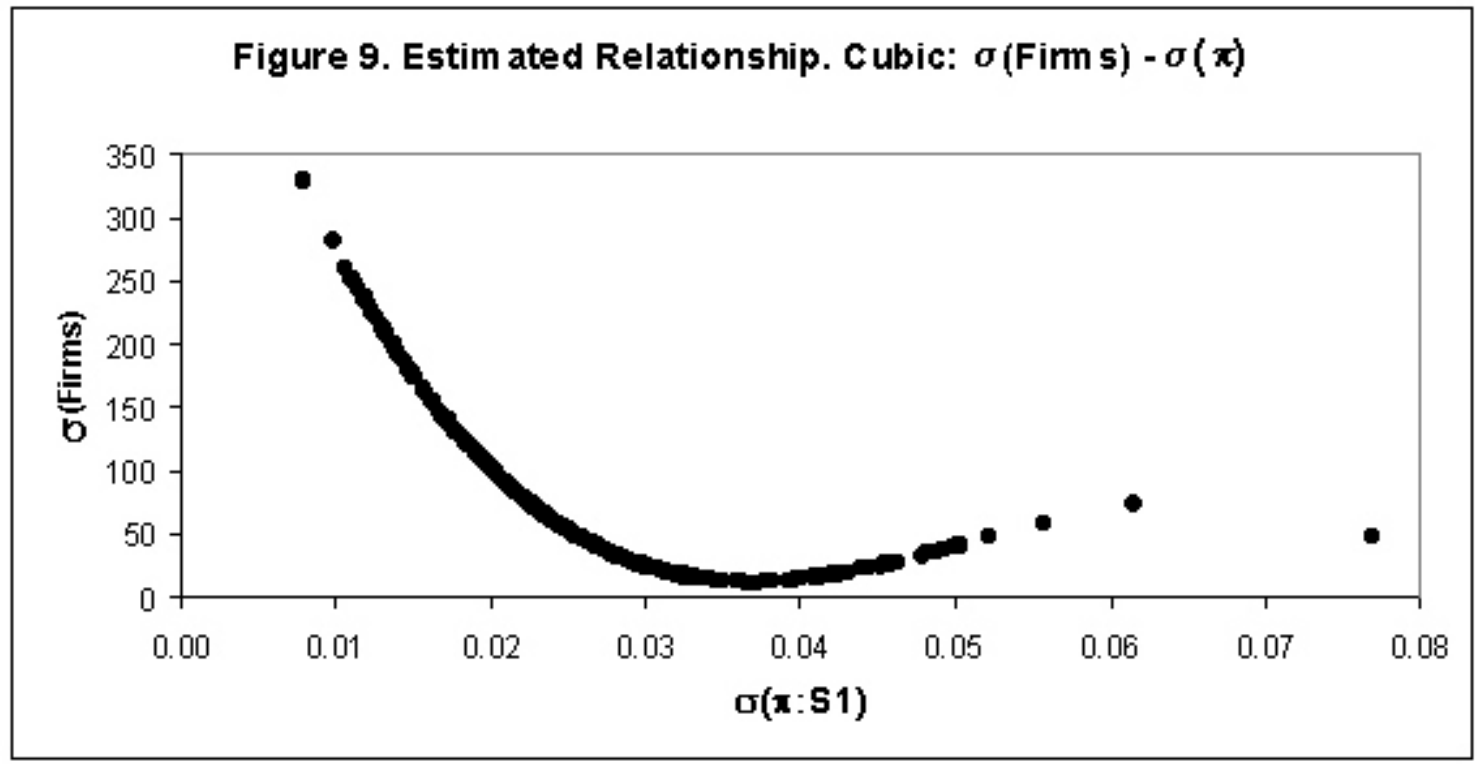

Notes: Equation (1) is modieifed to include cubic terms in $\sigma(\pi: S 1)$ and $\Phi(\mathrm{W})$. The estimated relationship between $\sigma($ Firms $)$ and $\sigma(\pi: \mathrm{S} 1)$ is evaluated at the mean values of the other variables. Also see notes to Figures 5-8-8. 

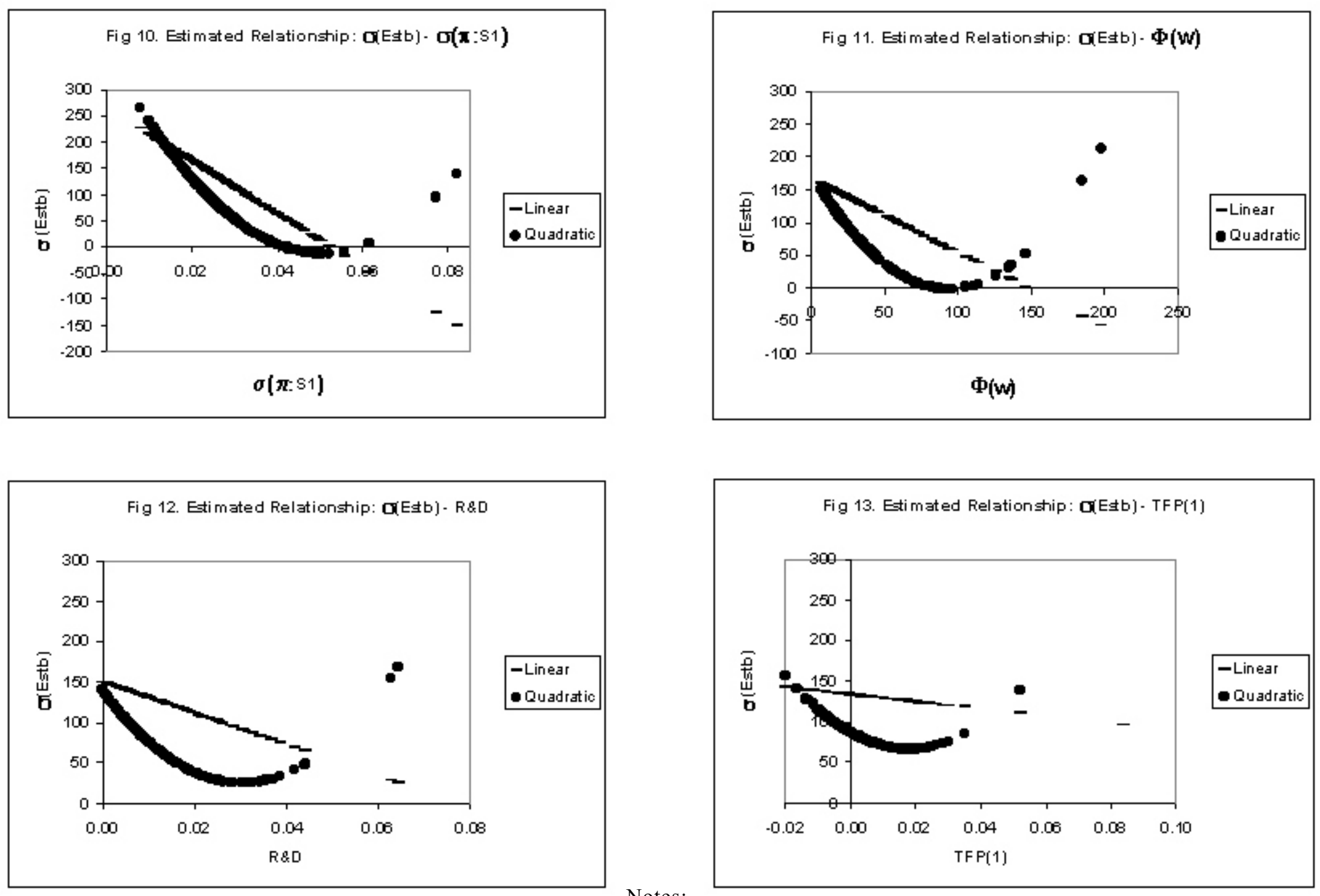

Figure 10, for example, presents the relationship between $\sigma($ Estb $)$ and $\sigma(\pi: \mathrm{S} 1)$ assuming all other variables are held at their mean values; similarly for Figures 11-13. See notes to Figures 1-4 for variables definitions. 


\title{
CESifo Working Paper Series
}

\author{
(for full list see www.cesifo.de)
}

914 Volker Grossmann, Managerial Job Assignment and Imperfect Competition in Asymmetric Equilibrium, April 2003

915 Christian Gollier and Richard Zeckhauser, Collective Investment Decision Making with Heterogeneous Time Preferences, April 2003

916 Thomas Moutos and William Scarth, Some Macroeconomic Consequences of Basic Income and Employment Subsidies, April 2003

917 Jan C. van Ours, Has the Dutch Miracle Come to an End?, April 2003

918 Bertil Holmlund, The Rise and Fall of Swedish Unemployment, April 2003

919 Bernd Huber and Marco Runkel, Optimal Design of Intergovernmental Grants under Asymmetric Information, April 2003

920 Klaus Wälde, Endogenous Business Cycles and Growth, April 2003

921 Ramon Castillo and Stergios Skaperdas, All in the Family or Public? Law and Appropriative Costs as Determinants of Ownership Structure, April 2003

922 Peter Fredriksson and Bertil Holmlund, Improving Incentives in Unemployment Insurance: A Review of Recent Research, April 2003

923 Bernard M.S. van Praag and Adam S. Booij, Risk Aversion and the Subjective Time Discount Rate: A Joint Approach, April 2003

924 Yin-Wong Cheung, Kon S. Lai, and Michael Bergman, Dissecting the PPP Puzzle: The Unconventional Roles of Nominal Exchange Rate and Price Adjustment, April 2003

925 Ugo Trivellato and Anna Giraldo, Assessing the 'Choosiness' of Job Seekers. An Exploratory Approach and Evidence for Italy, April 2003

926 Rudi Dornbusch and Stanley Fischer, International Financial Crises, April 2003

927 David-Jan Jansen and Jakob de Haan, Statements of ECB Officials and their Effect on the Level and Volatility of the Euro-Dollar Exchange Rate, April 2003

928 Mario Jametti and Thomas von Ungern-Sternberg, Assessing the Efficiency of an Insurance Provider - A Measurement Error Approach, April 2003

929 Paolo M. Panteghini and Guttorm Schjelderup, Competing for Foreign Direct Investments: A Real Options Approach, April 2003 
930 Ansgar Belke, Rainer Fehn, and Neil Foster, Does Venture Capital Investment Spur Employment Growth?, April 2003

931 Assar Lindbeck, Sten Nyberg, and Jörgen W. Weibull, Social Norms and Welfare State Dynamics, April 2003

932 Myrna Wooders and Ben Zissimos, Hotelling Tax Competition, April 2003

933 Torben M. Andersen, From Excess to Shortage - Recent Developments in the Danish Labour Market, April 2003

934 Paolo M. Panteghini and Carlo Scarpa, Irreversible Investments and Regulatory Risk, April 2003

935 Henrik Jacobsen Kleven and Claus Thustrup Kreiner, The Marginal Cost of Public Funds in OECD Countries. Hours of Work Versus Labor Force Participation, April 2003

936 Klaus Adam, George W. Evans, and Seppo Honkapohja, Are Stationary Hyperinflation Paths Learnable?, April 2003

937 Ulrich Hange, Education Policy and Mobility: Some Basic Results, May 2003

938 Sören Blomquist and Vidar Christiansen, Is there a Case for Public Provision of Private Goods if Preferences are Heterogeneous? An Example with Day Care, May 2003

939 Hendrik Jürges, Kerstin Schneider, and Felix Büchel, The Effect of Central Exit Examinations on Student Achievement: Quasi-experimental Evidence from TIMSS Germany, May 2003

940 Samuel Bentolila and Juan F. Jimeno, Spanish Unemployment: The End of the Wild Ride?, May 2003

941 Thorsten Bayindir-Upmann and Anke Gerber, The Kalai-Smorodinsky Solution in Labor-Market Negotiations, May 2003

942 Ronnie Schöb, Workfare and Trade Unions: Labor Market Repercussions of Welfare Reform, May 2003

943 Marko Köthenbürger, Tax Competition in a Fiscal Union with Decentralized Leadership, May 2003

944 Albert Banal-Estañol, Inés Macho-Stadler, and Jo Seldeslachts, Mergers, Investment Decisions and Internal Organisation, May 2003

945 Kaniska Dam and David Pérez-Castrillo, The Principal-Agent Matching Market, May 2003

946 Ronnie Schöb, The Double Dividend Hypothesis of Environmental Taxes: A Survey, May 2003 
947 Erkki Koskela and Mikko Puhakka, Stabilizing Competitive Cycles with Distortionary Taxation, May 2003

948 Steffen Huck and Kai A. Konrad, Strategic Trade Policy and Merger Profitability, May 2003

949 Frederick van der Ploeg, Beyond the Dogma of the Fixed Book Price Agreement, May 2003

950 Thomas Eichner and Rüdiger Pethig, A Microfoundation of Predator-Prey Dynamics, May 2003

951 Burkhard Heer and Bernd Süssmuth, Cold Progression and its Effects on Income Distribution, May 2003

952 Yu-Fu Chen and Michael Funke, Labour Demand in Germany: An Assessment of NonWage Labour Costs, May 2003

953 Hans Gersbach and Hans Haller, Competitive Markets, Collective Decisions and Group Formation, May 2003

954 Armin Falk, Urs Fischbacher, and Simon Gächter, Living in Two Neighborhoods Social Interactions in the LAB, May 2003

955 Margarita Katsimi, Training, Job Security and Incentive Wages, May 2003

956 Clemens Fuest, Bernd Huber, and Jack Mintz, Capital Mobility and Tax Competition: A Survey, May 2003

957 Edward Castronova, The Price of 'Man' and 'Woman': A Hedonic Pricing Model of Avatar Attributes in a Synthetic World, June 2003

958 Laura Bottazzi and Marco Da Rin, Financing Entrepreneurial Firms in Europe: Facts, Issues, and Research Agenda, June 2003

959 Bruno S. Frey and Matthias Benz, Being Independent is a Great Thing: Subjective Evaluations of Self-Employment and Hierarchy, June 2003

960 Aaron Tornell and Frank Westermann, Credit Market Imperfections in Middle Income Countries, June 2003

961 Hans-Werner Sinn and Wolfgang Ochel, Social Union, Convergence and Migration, June 2003

962 Michael P. Devereux, Measuring Taxes on Income from Capital, June 2003

963 Jakob de Haan, Jan-Egbert Sturm and Bjørn Volkerink, How to Measure the Tax Burden on Labour at the Macro-Level?, June 2003

964 Harry Grubert, The Tax Burden on Cross-Border Investment: Company Strategies and Country Responses, June 2003 
965 Kirk A. Collins and James B. Davies, Measuring Effective Tax Rates on Human Capital: Methodology and an Application to Canada, June 2003

966 W. Steven Clark, Using Micro-Data to Assess Average Tax Rates, June 2003

967 Christopher Heady, The 'Taxing Wages' Approach to Measuring the Tax Burden on Labour, June 2003

968 Michael P. Devereux and Alexander Klemm, Measuring Taxes on Income from Capital: Evidence from the UK, June 2003

969 Bernhard Eckwert and Itzhak Zilcha, The Effect of Better Information on Income Inequality, June 2003

970 Hartmut Egger and Josef Falkinger, The Role of Public Infrastructure for Firm Location and International Outsourcing, June 2003

971 Dag Morten Dalen and Trond E. Olsen, Regulatory Competition and Multi-national Banking, June 2003

972 Matthias Wrede, Tax Deductibility of Commuting Expenses and Residential Land Use with more than one Center, June 2003

973 Alessandro Cigno and Annalisa Luporini, Scholarships or Student Loans? Subsidizing Higher Education in the Presence of Moral Hazard, June 2003

974 Chang Woon Nam, Andrea Gebauer and Rüdiger Parsche, Is the Completion of EU Single Market Hindered by VAT Evasion?, June 2003

975 Michael Braulke and Giacomo Corneo, Capital Taxation May Survive in Open Economies, July 2003

976 Assar Lindbeck, An Essay on Welfare State Dynamics, July 2003

977 Henrik Jordahl and Luca Micheletto, Optimal Utilitarian Taxation and Horizontal Equity, July 2003

978 Martin D. D. Evans and Richard K. Lyons, Are Different-Currency Assets Imperfect Substitutes?, July 2003

979 Thorsten Bayindir-Upmann and Frank Stähler, Market Entry Regulation and International Competition, July 2003

980 Vivek Ghosal, Firm and Establishment Volatility: The Role of Sunk Costs, Profit Uncertainty and Technological Change, July 2003 